KEYWORDS

Tourism

Tourism infrastructure

Competitiveness

Measurement

Economic research

Econometric models

Tourism policy

Caribbean region

Bineswaree Bolaky

Economic Affairs Officer

Division for Africa, Least Developed Countries and Special Programmes;

United Nations Conference on

Trade and Development (UNCTAD)

๑ aruna_bolaky@yahoo.com

CEPAL REVIEW 104 - AUGUST 2011

\section{Tourism competitiveness in the Caribbean}

\author{
Bineswaree Bolaky
}

$\mathrm{T}$

his article analyses the main determinants of competitiveness in the Caribbean tourism stay-over industry using panel data for the period 1995-2006, based on an augmented version of an empirical model by Craigwell (2007). The ex post measure of competitiveness used is the share of world outbound tourists from Canada, the United Kingdom of Great Britain and Northern Ireland and the United States of America arriving in a Caribbean destination. The study finds evidence that Caribbean tourism competitiveness can be enhanced through policy measures that favour, among others, increases in investment, private sector development, better infrastructure, lower government consumption, a more flexible labour market, reduced vulnerability to natural disasters, higher human development and slow rises in oil prices. This article is an attempt to fill the gap on econometric research relating to tourism competitiveness for the Caribbean region. 


\section{I}

\section{Introduction}

Tourism is the dominant economic activity in the Caribbean, ${ }^{1}$ which is in fact the most tourism-penetrated region in the world. The establishment of tourism as a major economic activity was initially driven by a postindependence economic restructuring throughout the region away from traditional agriculture and towards services and manufacturing. This restructuring was deemed necessary in the face of declining competitiveness in traditional sectors (namely agriculture) and a need to build competitiveness in non-traditional areas.

According to the latest comprehensive report for the Caribbean published by the World Travel and Tourism Council (WTTC, 2004), travel and tourism demand in the region amounted to US\$ 40.3 billion in 2004 (out of US $\$ 5.5$ trillion worldwide, or $0.7 \%$ of the total), and is expected to rise to US $\$ 81.9$ billion by 2014 . By this indicator, the largest travel and tourism economies in the Caribbean are Puerto Rico (22.4\% of total regional demand), the Dominican Republic (12.9\%), Cuba (12.0\%), the Bahamas (9.0\%) and Jamaica (8.2\%). These five destinations account for almost two thirds of the total market demand. The smallest travel and tourism economies are Anguilla, Dominica, Grenada, Saint Kitts and Nevis and Saint Vincent and the Grenadines, accounting for $1.7 \%$ of the total demand. In terms of output generation, three small island groups (Anguilla, Antigua and Barbuda and the British Virgin Islands) have more than $70 \%$ of their gross domestic product (GDP) originating in the travel and tourism industry. For Aruba, the Bahamas and Barbados, the contribution of this sector to GDP lies in the range of $50 \%-70 \%$. In terms of job creation, travel and tourism activities account for more than two thirds of employment in Anguilla, Aruba, the Bahamas, Antigua and Barbuda and the British Virgin Islands, the figures being $95 \%$ for the latter two. For another seven Caribbean countries (Barbados, Cayman Islands, Jamaica, Saint Kitts and Nevis, Saint Lucia, Saint Vincent and the Grenadines and the United States Virgin Islands), employment dependency ranges between $30 \%$ and $60 \%$; and for a further five countries (Bermuda, Dominica,

$\square$ The views expressed in this article are those of the author and do not necessarily reflect the views of the Organization.

${ }^{1}$ Defined as the 32 member countries and territories of the Caribbean Tourism Organization excluding Mexican destinations (Cancún and Cozumel).
Dominican Republic, Grenada and Guadeloupe), the range is between $15 \%$ and $30 \% .^{2}$

In a regional report, wTTC estimated that the travel and tourism economy contributed about $14.5 \%$ to the region's GDP in 2009, the highest level in the world (WTTC, 2009). The sector also generated some $2,052,000$ jobs, or $11.9 \%$ of total employment. However, the report also ranked the Caribbean as the region with the second-weakest expected annual real GDP growth rate from tourism for the next 10 years. These figures seem to point to one major conclusion: the Caribbean is the most tourism-dependent region in the world and yet its prospects for future growth are not as bright as in other regions, such as Asia. The high dependency of most Caribbean States on tourism makes it imperative for the region as a whole to understand and analyse the major determinants of its tourism competitiveness. Such analysis can contribute to informing policymakers on the choice of public policies and strategies that the tourism sector needs in order to enhance its competitiveness.

From the outset, there is a need to recognize, however, that competitiveness in Caribbean tourism is a long-standing issue. In 2005, for instance, the World Bank published a report on the state of competitiveness in the Caribbean highlighting that the Caribbean Community (CARICOM) tourism sector's performance had, in recent years, not lived up to expectations and that tourism growth in the Caribbean tended to lag world growth (World Bank, 2005). The report recommended that the region should put in place strategies to increase competitiveness.

This study estimates an empirical model of competitiveness in the tourism sector using panel data for 32 Caribbean countries over the period 19952006. Such an exercise is necessary in order to define viable competitiveness strategies for the region based on empirical analysis. The second section defines the concept of tourism competitiveness and discusses its major determinants and measures. In the third section, the model to be estimated is introduced, while the fourth section presents some econometric results on the main drivers of tourism competitiveness in the Caribbean. The fifth section presents the author's conclusions.

\footnotetext{
2 All figures in this paragraph refer to 2004 unless otherwise indicated, as reported by the WTTC 2004 report.
} 


\section{II}

\section{Measures and Determinants of Tourism Competitiveness}

Tourism competitiveness is influenced by a wide set of factors or determinants. The literature on tourism recognizes tourism competitiveness as a relative, multidimensional, complex concept determined by a range of economic, political, ecological and cultural variables (Craigwell, 2007).

An ex ante measure of tourism competitiveness that has been commonly used is the WTTC Tourism Competitiveness Index, which is built around eight dimensions: (i) price competitiveness; (ii) infrastructure development; (iii) environmental quality; (iv) technology advancement; (v) degree of openness; (vi) human resources; (vii) social development; and (viii) human tourism indicators. This index focuses on the macroeconomic determinants of competitiveness and sheds light on the competitive strengths and weaknesses of tourist destinations. Table 1 summarizes and describes the different components of the index.

The World Economic Forum has taken over the wTTC Tourism Competitiveness Index and since 2007 has produced the Travel and Tourism Competitiveness Index for 124 countries, rating them on three dimensions: travel and tourism regulatory framework; business environment and infrastructure; and human, cultural and natural resources. Table 2 summarizes and describes the different components of this index. Both price and non-price determinants of competitiveness are factored in.

TABLE 1

World Travel and Tourism Council Tourism Competitiveness Index: main sub-indexes and components

\begin{tabular}{ll}
\hline Main sub-indexes & Components \\
\hline Price competitiveness & Hotel prices, indirect taxes, purchasing power parities \\
Human tourism & Volume and value of inbound and outbound tourism \\
Infrastructure & Roads, railways, water, sanitation \\
Environment & Population density, carbon emissions, ratification of international treaties on the environment \\
Technology & Internet access, telephones, mobile telephones, high-tech exports \\
Human resources & Life expectancy, literacy, school enrolment rates, employment in travel and tourism, unemployment, \\
population, gender indicators
\end{tabular}

Source: World Travel and Tourism Council, Tourism Satellite Accounting, London, 2006.

TABLE 2

World Economic Forum Travel and Tourism Competitiveness Index: main subindexes and components

\begin{tabular}{ll}
\hline Main sub-indexes & Components \\
\hline Regulatory framework & $\begin{array}{l}\text { Policy rules and regulations, environmental regulation, safety and security, health and } \\
\text { hygiene, and prioritization of travel and tourism strategies }\end{array}$ \\
Business environment and infrastructure & $\begin{array}{l}\text { Air transport infrastructure, ground transport infrastructure, tourism infrastructure, } \\
\text { information and communications technology infrastructure, and price competitiveness } \\
\text { Human, cultural and natural resources }\end{array}$ \\
$\begin{array}{l}\text { Education and training, availability of qualified labour, workforce wellness, national } \\
\text { tourism perception, and natural and cultural resources }\end{array}$
\end{tabular}

Source: World Economic Forum, The Travel \& Tourism Competitiveness Report 2007: Furthering the Process of Economic Development, Geneva, 2007. 


\section{III}

\section{Empirical Modelling}

Craigwell (2007) assumes that a country's international stay-over tourist arrivals $(V)$ depend on three key factors: technological advantage $(A)$; industrial organizational advantage $(O)$ and price advantage $(P)$. The author also postulates that a change in a country's tourist arrivals from period $T-1$ to $T$ will be driven by deviations in the competitiveness conditions of that country's tourism sector relative to those prevailing in its competitors. In the present study, the framework used by Craigwell is refined and augmented by borrowing both from the model of destination competitiveness of Dwyer and Kim (2003) and the WTTC Tourism Competitiveness Index outlined above to postulate that:

$$
V=\Phi(P, I, E, A, O, S, E X)
$$

where

$P=$ Price competitiveness advantages;

$I=$ Infrastructure advantages;

$E=$ Environmental advantages;

$A=$ Technological advantages;

$O=$ Industrial organizational advantages reflecting the market-based conditions that can influence the competitive environment faced by firms and industries, such as the degree of openness, government intervention, access to human resources, access to finance and regulatory environment;

$S=$ Social advantages, including quality of the human environment, such as health and sanitation;

$E X=$ Exogenous advantages determined by history, culture and geography.

The estimated panel regression equation is of the following form:

$$
\begin{gathered}
S_{i j t}=\frac{V_{i j t}}{V_{i t}}=\alpha+\beta_{1} P_{i j t}+\beta_{2} I_{j t}+\beta_{3} E_{j t}+\beta_{4} A_{j t}+ \\
\beta_{5} O_{j t}+\beta_{6} S_{j t}+\beta_{7} E X_{j}+\varepsilon_{j t}
\end{gathered}
$$

where

$S_{i j t}=$ Tourism performance indicator reflecting ex post competitiveness of Caribbean destination $j$ from source market $i$ in year $t$;

$V_{i j t}=$ Total stay-over tourist arrivals at Caribbean destination $j$ from source market $i$ in year $t$, where $i=$ Canada, the United Kingdom and the United States (the three main source markets in the Caribbean);

$V_{i t}=$ Total world outbound tourists from Canada, the United Kingdom and the United States in year $t$;

$P_{i j t}=$ Measures of price competitiveness advantages for Caribbean destination $j$ vis-à-vis source market $i$ in year $t$;

$I_{j t}=$ Measures of infrastructure advantages for Caribbean destination $j$ in year $t$;

$E_{j t}=$ Measures of environmental advantages for Caribbean destination $j$ in year $t$;

$A_{j t}=$ Measures of technological advantages for Caribbean destination $j$ in year $t$;

$O_{j t}=$ Measures of industrial organizational advantages for Caribbean destination $j$ in year $t$;

$S_{j t}=$ Measures of social advantages for Caribbean destination $j$ in year $t$;

$E X_{j}=$ Measures of exogenous advantages for Caribbean destination $j$ (fixed factors);

$\varepsilon_{j t}=$ Disturbance term for Caribbean destination $j$ in year $t$, which can be decomposed into $\varepsilon_{j t}=\eta_{j}+$ $v_{j t}$, where $\eta_{j}$ is a country-specific random error term with mean zero and constant variance and $v_{j t}$ is a random disturbance term that has mean zero and constant variance for each country $j$ and varies across $j$.

Assumptions: $E\left(\varepsilon_{j t}\right)=0$, that is, $\varepsilon_{j t}$ has mean zero; $\operatorname{Var}\left(\varepsilon_{i t}\right)=\sigma_{j}$, that is, $\varepsilon_{j t}$ has constant variance within each country $j$ but varies across $j$; $\operatorname{Cov}\left(\varepsilon_{j t}, X_{j t}\right)=$ $\operatorname{Cov}\left(\eta_{j}, X_{j t}\right)=\operatorname{Cov}\left(v_{j t}, X_{j t}\right)=0$, that is, the error terms and their components are uncorrelated with the explanatory variables $X_{j t} ; E\left(\varepsilon_{j t}, \varepsilon_{j t+1}\right)=0$, that is, there is no serial autocorrelation in error term within a country $j$; and $E\left(\varepsilon_{s t}, \varepsilon_{j t+1}\right)=0$, that is, there is no contemporaneous correlation in the error terms across any countries $j$ and $s$.

These assumptions imply that the panel regression equation will be estimated under the assumption of crosssectional heteroskedasticity. The model is estimated using three alternative methods: ordinary least squares (oLs) (pooled regressions), generalized least squares (GLS) and random effects (RE). The latter is preferred over fixed effects according to standard Hausman tests. 


\section{IV}

\section{Econometric Results}

\section{Variables and data description}

The starting point is a sample that consists of the 32 member countries and territories of the Caribbean Tourism Organization (excluding the Mexican destinations indicated in footnote 1) for the period 1995-2006, resulting in a potential maximum sample of 384 annual observations.

Dwyer, Forsyth and Rao (2000) distinguish between two components of tourism price competitiveness $(P)$ for a destination: a component that reflects the cost of ground content at the destination (accommodation, tour services, food and beverage, entertainment etc.) and a component that reflects the cost of transport services to and from the destination and the source market. Based on this, in a first instance two measures of price competitiveness are included in the regression equation, namely (i) the bilateral real exchange rate calculated as the ratio of the price level in the source market to the price level at the destination denominated in the latter's national currency; and (ii) the growth rate of international oil prices. The latter is used as a proxy for airfares between the destination and the source market and as a proxy for the costs of ground transport at the destination.

In a second instance, three measures of transport costs are also included, one per source market. Following Craigwell (2007), these are constructed as the product of the growth rate in oil prices and the geographical travelling distance from the source market to the Caribbean destination relative to the distance from the source market to the destination's major non-Caribbean competitor. The growth rate in prices is taken instead of the price level itself because of the non-stationary behaviour of the latter. This implies that tourism competitiveness is more sensitive to the pace of growth in oil prices rather than to the growth in oil prices alone. Faster and larger increases in oil prices hurt tourism competitiveness much more than slow, moderate increases, as the former are likely to pass through faster to transport costs. ${ }^{3}$ For

\footnotetext{
${ }^{3}$ An increase in oil prices by, say, $1 \%$ may cause transport companies not to increase their prices in order not to lose customers. However, a high increase in oil prices by, say, $10 \%$ may incite transport companies to immediately adjust their prices, passing that increase through as higher transport costs in order to prevent large losses in profits. In addition, there are costs to transport companies for adjusting their
}

the British source market, the major non-Caribbean competitor is taken to be Spain; for the United States, it is taken to be Mexico; and for Canada, it is taken to be the United States and is proxied to be Florida. ${ }^{4}$ It is expected that the share of American, British and Canadian tourists to each Caribbean destination will increase with a real depreciation of the local currency relative to the source market's currency, with slower rate of growth in oil prices and with lower transport costs.

As a measure of infrastructural competitive advantage $(I)$, the share of real gross fixed capital formation in GDP is used as a proxy for infrastructure and capital upgrading. ${ }^{5}$ This measure should capture investment efforts in expanding and improving general infrastructure at the destination. It is expected that tourism competitiveness increases with higher levels of infrastructure investment.

Population density and an index of environmental vulnerability are used to capture environmental advantages $(E)$. The former is expected to reduce tourism competitiveness to the extent that it is associated with factors such as overcrowding, pollution or environmental degradation that may reduce the attractiveness of the destination to certain types of tourists, especially ecotourists. However, population density can also be associated with a higher prevalence of urban, leisure and cultural facilities, such as shopping, entertainment and sports, which may increase the attractiveness of the destination to other types of tourists in certain niche markets (shopping, sports, gambling and the like). The effect of population density on tourism competitiveness is therefore ambiguous.

Higher environmental vulnerability however - for instance, exposure to natural disasters such as hurricanes, environmental degradation and marine pollution- is

prices in relation to fuel costs; these adjustment costs fall with faster and larger increases in fuel costs.

4 In 2006, according to statistics of the World Tourism Organization (UNWTO), Spain was the top tourist destination for British tourists, Mexico was the top tourist destination for Americans and the United States was the top tourist destination for Canadians.

5 This measure includes government expenditure on investment but excludes government expenditure on consumption of goods and services. Although, ideally, investment in the tourism sector alone should have been used, such sector-specific gdp data are unfortunately not available. 
expected to reduce tourism competitiveness. In the Caribbean context, exposure to natural disasters, such as hurricanes, can have a strong impact on tourism performance. This particular determinant is entered as a fixed factor in the regression using data from the United Nations Environment Programme and the South Pacific Applied Geoscience Commission's environmental vulnerability index, which is available for a single year only. The expectation is that greater exposure to natural disasters reduces the attractiveness of a destination as a safe haven and impacts negatively on its competitiveness.

Technological competitiveness advantage $(A)$ is captured in the regression equation by the inclusion of an indicator on telephone mainlines in use, with the expectation that such an indicator is likely to be positively correlated with other sources of technological advantages reflected in the WTTC Tourism Competitiveness Index, such as Internet access or mobile telephone use. Access to good technology not only raises tourism competitiveness by increasing the attractiveness of a destination as a comfortable destination for tourists, it also raises the destination's attractiveness as an investment location for tourism investors whose capital finances the expansion of supply in the tourism sector. Due to limited data availability, telephone mainlines are used as the sole indicator of technological advantage; and the initial values at the start of the sample alone are used to minimize gaps in the time series data.

Industrial organizational advantages $(O)$ are taken to reflect factors that will affect the competitiveness of the business environment faced by firms in the tourism industry. Four main factors are identified that can affect the cost competitiveness of the destination tourism industry: local private sector development, degree of trade openness, labour market competitiveness and government intervention in the economy.

The tourism sector is input-intensive; in destinations where the local private sector is undeveloped, this translates into high import-intensiveness as most inputs need to be imported rather than sourced locally at cheaper prices. Import leakage rates in the Caribbean tourism sector are recognized to be very high (ECLAC 2003 and 2008a). Support for development of the local private sector at tourism destinations can raise tourism price competitiveness by making cheaper local inputs available. It can also raise the attractiveness of the destination by making a range of privately supplied facilities available to tourists, thereby expanding the domestic tourism value chain. Accordingly, domestic credit to the private sector as a share of GDP is included in the regression equation to capture this dimension. In addition, open trade policies that stifle domestic private sector development and increase import dependency may harm tourism competitiveness. However, openness to trade can also facilitate the use of cheaper and higherquality imported inputs over dearer and lesser-quality local inputs for the tourism sector, thereby augmenting competitiveness. Overall, trade openness can either benefit or harm tourism competitiveness and this remains to be settled empirically. A measure of trade openness (namely, exports plus imports as a share of GDP) is entered in the regression equation to control for this factor.

Tourism is also a labour-intensive industry (Jayawardena, 2002). Tourism competitiveness therefore will directly depend on labour market conditions in the destination country. Factors such as real wage levels, ease of hiring and firing workers, labour regulations and quality of human resources will affect the destination's cost competitiveness. In Caribbean countries with fixed exchange rate regimes, wage competitiveness and rising labour productivity become especially relevant as drivers of cost competitiveness. Competitiveness of the labour market is accounted for by entering an employment index measuring rigidity in the labour market ${ }^{6}$ in the regression equation. The data are taken from the World Bank's Doing Business database. Data for the Caribbean are available from the year 2006 onwards. Under the assumption that labour market reforms are slow to occur and that institutional quality takes time to improve, the earliest observation available for each destination is used to enter the index as a time-invariant factor in the equation.

Tourism is, moreover, essentially a private sector activity, though it needs an appropriate physical, regulatory, fiscal and social framework to grow in a sustainable fashion that can only be provided by governments or public sector authorities (UNWTO, 2000). In accordance with current literature, this article recognizes the early role played by government incentives in stimulating development of the tourism industry in the Caribbean. Such tourism-targeted public incentives have included in the past preferential tax treatment, tax exemptions, guarantees such as profit repatriation for foreign investors, streamlining of procedures and provision of tourismrelated services. However, the effectiveness of these incentives in maintaining the Caribbean as a competitive

\footnotetext{
6 The rigidity of employment index is an average of three indices that measure how difficult it is to hire new workers, how rigid the regulations on working hours are and how difficult it is to dismiss a redundant worker.
} 
destination has been questioned. ${ }^{7}$ In addition, such types of incentive have been emulated in other regions, thereby blunting their effectiveness as a driver of competitiveness for the Caribbean relative to other regions. In the absence of data on real government expenditure by sector, the share of real government final consumption expenditure in GDP is added as a proxy to reflect targeted public spending on tourism. However, the share of real government final consumption expenditure in GDP can also capture distortion-inducing government activity in the economy that can harm tourism competitiveness. For instance, high government consumption financed by higher taxes on the private sector (including the private tourism sector) will harm tourism competitiveness.

To reflect social advantages $(S)$, such as level of human development, as a determinant of a destination's tourism competitiveness, two health-related variables are included in the equation, namely start-of-sample values for the tuberculosis death rate per 100,000 inhabitants and the number of new HIV/AIDS cases reported. ${ }^{8}$ The quality of the health environment, and environmental safety in general, have been recognized as important factors affecting tourism arrivals in the Caribbean (Caribbean Epidemiology Center (CAREC)/Pan American Health Organization (PAHO)). ${ }^{9}$ It is expected that improvements in health and human development indicators will raise the attractiveness of a country as a safe and comfortable destination. Owing to the limited availability of data on crime and murder rates, this variable is left out.

Lastly, a set of exogenously given determinants of destination competitiveness $(E X)$ is included in the regression equation. These determinants can be fixed factors intended to account for size, historical and cultural advantages that a particular destination may possess. A dummy variable for former British and Spanish colonies is included to reflect any advantages a destination may

\footnotetext{
${ }^{7}$ According to the World Bank (2005), Caribbean governments have long relied on the use of incentives to attract foreign investment in the tourism industry, sometimes granting preferential treatment to larger international investors. However, the same report notes that most countries in fact now offer similar types of incentive, thereby levelling the playing field in terms of competitive advantages. In addition, the report questions the effectiveness of some of these incentives; for instance, tax incentives can be discretionary and introduce elements of uncertainty for foreign and domestic investors alike (page 108). While a detailed discussion of such incentives lies outside the scope of this article, the interested reader can refer to Duval (2005) for further discussion.

8 Initial values alone are used to minimize significant gaps in time series.

${ }^{9}$ The reader can refer to http://www.carec.org/projects/hotels/qtc_project. htm for an overview of the carec/paho Quality Tourism for the Caribbean initiative, which is aimed at promoting competitiveness in tourism by promoting health and environmental safety and standards.
}

have for a given source market on account of historical or colonial background, language ties or cultural heritage. It is expected that the coefficient of the Spanish dummy variable will be large and significant given the dominance of the three Spanish-speaking countries in Caribbean tourism, in terms of both level and growth of stay-over arrivals (Cuba, the Dominican Republic and Puerto Rico account for $45 \%-50 \%$ of the total stay-over market in the Caribbean). However, it is also expected that Englishspeaking countries have a relative advantage for American, British and Canadian source markets.

Exogenously given determinants that relate to domestic conditions in the source markets or world business conditions are also controlled for. Real income growth in the source markets as an exogenous determinant of tourism competitiveness is included, with the expectation that faster real income growth in source markets raises Caribbean tourism competitiveness relative to other regions closer to these source markets, as the purchasing power of the visitors increases and makes longdistance travel more affordable. A weighted average index of real income growth across the three source markets is constructed with the weights given by the initial share of these source markets in total stay-over arrivals in the given destination. Lastly, time dummy variables for the period 1995-2005 are included to control for changes in the given external world environment. Table 3 provides a summary description of the variables and the sources used.

The final sample consists of only 80 observations out of a potential 384 due to limited data availability for most Caribbean States and territories. Nine countries are covered; they are Belize, the Dominican Republic, Grenada, Jamaica, Saint Kitts and Nevis, Saint Lucia, Saint Vincent and the Grenadines, Suriname and Trinidad and Tobago. Panel unit root tests (Levin-Lin-Chu tests) were carried out to ensure that all explanatory variables are stationary. Simple correlation coefficients between the dependent variable $S_{i j}$ and each explanatory variable were also calculated. ${ }^{10}$

\footnotetext{
${ }^{10}$ At a $10 \%$ level of significance, we find that the significant positive correlates with the tourism competitiveness indicator in the sample are: the former Spanish colony dummy variable, the number of new cases of HIV/AIDS reported and the tuberculosis prevalence rate. The significant negative correlates include: a weighted index of real exchange rate appreciation between the currency of the destination relative to the currencies of the three source markets (both when aggregated across all three source markets and when disaggregated by source market), real government final consumption expenditure in GDP, trade openness, domestic credit to the private sector as a percentage of GDP, the former British colony dummy variable and the number of telephone mainlines in use per 100 inhabitants. The unit root test and correlation coefficients are available upon request from the author.
} 
TABLE 3

Summary description of variables

\begin{tabular}{|c|c|c|}
\hline Variable & Description & Sources \\
\hline$S_{i j}$ & $\begin{array}{l}\text { Share of American, British and Canadian stay-over arrivals (aggregated) } \\
\text { to destination } j \text { in total world outbound American, British and } \\
\text { Canadian tourist arrivals } \\
i=\text { Source markets (Canada, United Kingdom and United States) } \\
j=\text { Caribbean destination } \\
S_{i j}=\left(T_{U K j}+T_{U S j}+T_{C A N j}\right) /\left(W_{U K}+W_{U S}+W_{C A N}\right) \\
\text { where } T_{i j}=\text { Total stay-over arrivals to destination } j \text { from source } i \text {; and } \\
W_{i}=\text { total world outbound stay-over tourists from country } i \text {. }\end{array}$ & World Tourism Organization \\
\hline$Y_{j}$ & $\begin{array}{l}\text { Weighted average of GDP growth in Canada, the United Kingdom and } \\
\text { the United States; weights are shares of each of those three countries } \\
\text { in the total stay-over market of Caribbean destination } j \text { as at } 1995 \text {. } \\
\text { These shares are adjusted so that the weights sum to } 1 .\end{array}$ & $\begin{array}{l}\text { World Bank (World Development Indicators); } \\
\text { Caribbean Tourism Organization }\end{array}$ \\
\hline $\begin{array}{l}Y_{U S} \\
Y_{w}\end{array}$ & $\begin{array}{l}\text { GDP growth rate of the United States and GDP growth rate of the } \\
\text { world, respectively }\end{array}$ & World Bank (World Development Indicators) \\
\hline$G P O I L$ & $\begin{array}{l}\text { Annual growth rate in world crude oil prices (United States dollars } \\
\text { per barrel) }\end{array}$ & Energy Information Administration \\
\hline $\begin{array}{l}T C_{U K, j} \\
T C_{U S, j} \\
T C_{C A N, j}\end{array}$ & $\begin{array}{l}\text { Transport costs from Canada/United Kingdom/United States to } \\
\text { destination } j \text { calculated as the product of growth rate in oil prices and } \\
D I S T_{U K, j} \text {, or } D I S T_{U S, j} \text {, or } D I S T_{C A N, j} \text {, respectively where: } \\
\text { DIST }_{U K, j}=\text { Distance from the United Kingdom international airport } \\
\text { (London Heathrow) to the main international airport of Caribbean } \\
\text { destination } j \text { relative to the distance from the United Kingdom } \\
\text { international airport (London Heathrow) to the Spain international } \\
\text { airport (Madrid) } \\
\text { DIST }_{U S, j}=\text { Distance from the United States international airport } \\
\text { (New York John F. Kennedy) to the main international airport of } \\
\text { Caribbean destination } j \text { relative to the distance from the United States } \\
\text { international airport (New York John F. Kennedy) to the Mexico } \\
\text { international airport (Mexico City) } \\
\text { DIST } C A N, j=\text { Distance from the Canada international airport (Toronto } \\
\text { Pearson) to the main international airport of Caribbean destination } j \\
\text { relative to the distance from the Canada international airport (Toronto } \\
\text { Pearson) to the United States international airport (Miami, using } \\
\text { Florida as a proxy) }\end{array}$ & $\begin{array}{l}\text { Energy Information } \\
\text { Administration www.webflyer.com }\end{array}$ \\
\hline$R E R_{j}$ & $\begin{array}{l}\text { Weighted average of real exchange rate of Canada, the United } \\
\text { Kingdom and the United States; weights are share of each of those } \\
\text { three countries in the total stay-over market of Caribbean destination } j \\
\text { as at } 1995 \text {. These shares are adjusted so that the weights sum to } 1 \text {. }\end{array}$ & United Nations Common Database \\
\hline $\begin{array}{l}R E R_{U K, j} \\
R_{U E R_{U S, j}} \\
R_{C A} R_{C A N, j}\end{array}$ & $\begin{array}{l}\text { Real exchange rate of source country } i \text { relative to Caribbean destination } \\
j \text { is calculated as follows: } \\
R E R_{i, j}=\left(P_{i} / P_{j}\right)^{*} E \\
E=\text { Nominal exchange rate of local currency per United States } \\
\text { dollar divided by nominal exchange rate of source market } i \text { per } \\
\text { dollar = Nominal exchange rate of source market } i \text { currency per local } \\
\text { currency } \\
P=\text { GDP deflators (base 1990, national currency) as proxies for price } \\
\text { levels }\end{array}$ & \\
\hline$I N V_{j}$ & $\begin{array}{l}\text { Share of gross fixed capital formation in GDP (at constant prices, } \\
\text { national currency) }\end{array}$ & United Nations Common Database \\
\hline$G C O N S_{j}$ & $\begin{array}{l}\text { Share of government final consumption expenditure in GDP (at constant } \\
\text { prices, national currency) }\end{array}$ & United Nations Common Database \\
\hline$T_{R A D E O P E N}$ & $\begin{array}{l}\text { Ratio of the sum of exports and imports of goods and services to gdp } \\
\text { (at constant prices, national currency) }\end{array}$ & United Nations Common Database \\
\hline POPDENS & $\begin{array}{l}\text { Population density calculated as total population divided by total land } \\
\text { area in hectares }\end{array}$ & United Nations Common Database \\
\hline $\mathrm{CREDITPS}_{j}$ & Domestic credit to private sector (percentage of GDP) & World Bank (World Development Indicators) \\
\hline
\end{tabular}


(concluded)

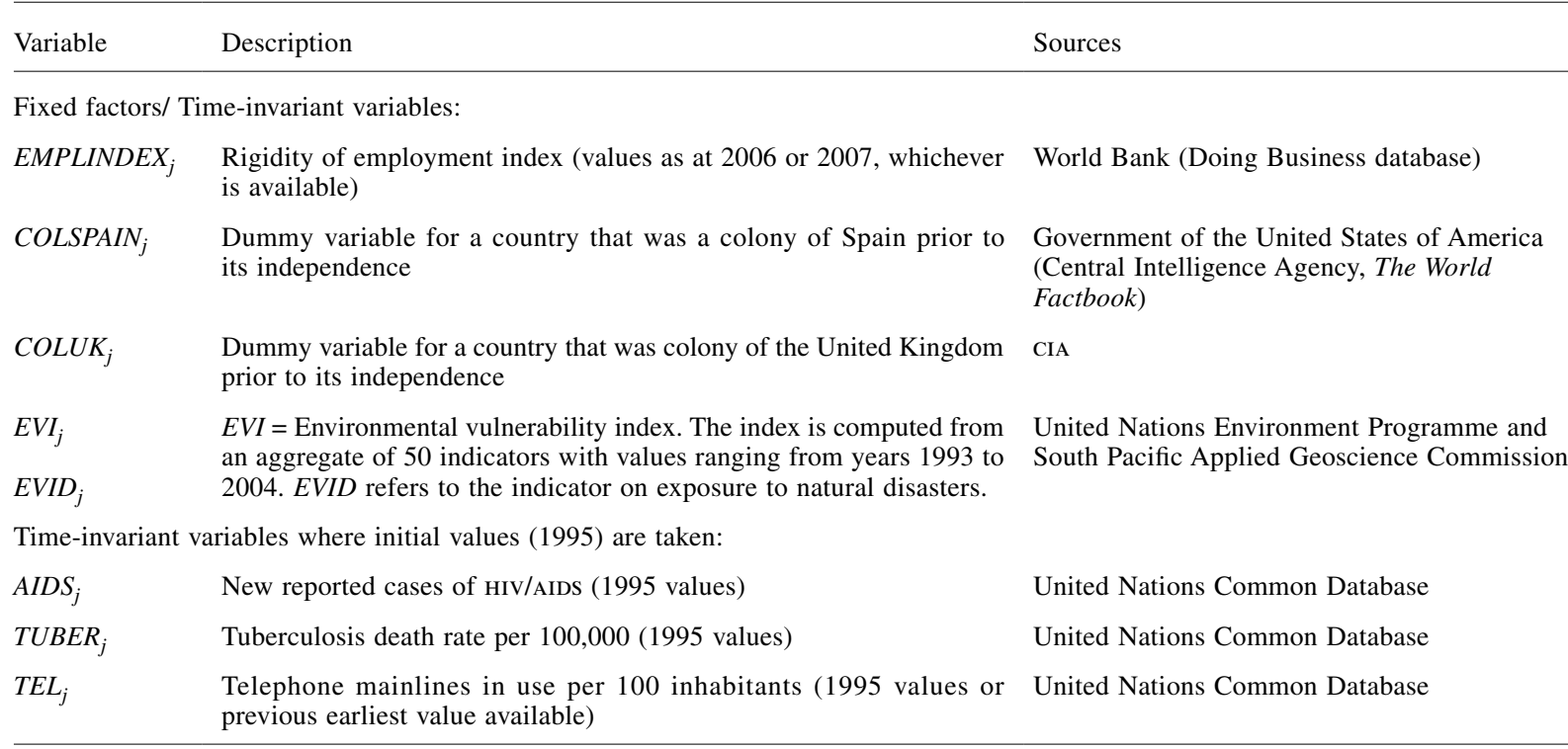

Source: Prepared by the author.

\section{Regression results}

Table 4 shows two sets of regression estimation results for two different equation specifications (A and B), using pooled ordinary least squares (OLS), pooled generalized least squares (GLS) and random effects (RE) model estimations, all allowing for cross-sectional heteroskedasticity. To verify the appropriateness of the latter method as opposed to the fixed effects (FE) model estimation, Hausman tests were performed to check for the non-correlation of the country-specific random term $\left(\eta_{j}\right)$ in the error term with the explanatory variables under both specifications A and B. In both cases, the null hypothesis that the random effects model produces efficient estimators could not be rejected at the $1 \%$ level of significance. It is worth noting the high goodness of fit of all regressions, as revealed by an $\mathrm{R}$-squared value of $98 \%$ in the OLS and RE estimations, coupled with Wald chi-squared statistics that are statistically different from zero in all regressions regardless of the estimation method used. These results imply a rejection of the null hypothesis that all explanatory variables taken together are statistically insignificant in affecting the behaviour of tourism competitiveness.

In model specification $\mathrm{A}$, the real income growth variable is included as a weighted average of the GDP growth rate in each source country $\left(Y_{j}\right)$ as defined in table 3 . The same is true in the case of the real exchange rate variable $\left(R E R_{j}\right)$. Likewise, the rate of growth of oil prices (GPOIL) is included as a single proxy variable for transport costs. The econometric results provide evidence at the $1 \%$ level of significance that tourism competitiveness in the Caribbean is negatively affected by real appreciation of the local currency relative to the currencies of the source markets, trade openness (TRADEOPEN), rigidity in employment conditions (EMPINDEX), exposure to natural disasters (EVID) and the prevalence rate of HIV/ AIDS. These results hold independently of the estimation method used (OLS, GLS or RE).

In addition, higher rates of growth in oil prices are found to depress tourism competitiveness using either the oLS or the GLS method, although only at the $10 \%$ level of significance. Former British colonies are found to be at a competitive disadvantage relative to other former colonies, despite their language advantage, as revealed by the negative estimated parameter associated with COLUK. This result may be driven by the presence of the Dominican Republic in the sample, which is one of the three dominant Spanish-speaking markets in Caribbean tourism (together with Cuba and Puerto Rico). The other side of the coin is confirmed as well, i.e. that former Spanish colonies have a large competitive edge in the region relative to other former colonies, as evidenced by the relative high positive values exhibited by the estimated parameters linked to COLSPAIN, which are statistically different from zero at the $1 \%$ level of 
TABLE 4

Regression results ${ }^{\mathbf{a}}$

(Dependent variable $S_{i j}{ }^{b}$; sample 1995-2006; annual frequency)

\begin{tabular}{|c|c|c|c|c|c|c|}
\hline & \multicolumn{3}{|c|}{ Model specification A } & \multicolumn{3}{|c|}{ Model specification B } \\
\hline & $\mathrm{OLS}^{\mathrm{c}}$ & $\mathrm{GLS}^{\mathrm{d}}$ & Random Effects & $\mathrm{OLS}^{\mathrm{c}}$ & $\mathrm{GLS}^{\mathrm{d}}$ & Random Effects \\
\hline$Y_{j}$ & $\begin{array}{l}-0.0004 \\
(0.510)\end{array}$ & $\begin{array}{l}-0.0001 \\
(0.808)\end{array}$ & $\begin{array}{l}-0.0004 \\
(0.604)\end{array}$ & .. & .. & .. \\
\hline$Y_{U S}$ & .. &.. & .. & $\begin{array}{l}0.3371 * \\
(0.094)\end{array}$ & $\begin{array}{l}0.3238^{*} \\
(0.088)\end{array}$ & $\begin{array}{c}0.3371 \\
(0.191)\end{array}$ \\
\hline$Y_{w}$ & .. &.. & .. & $\begin{array}{l}1.4045^{*} \\
(0.061)\end{array}$ & $\begin{array}{l}1.2898 * \\
(0.068)\end{array}$ & $\begin{array}{r}1.4045 \\
(0.143)\end{array}$ \\
\hline GPOIL $_{j}$ & $\begin{array}{l}-0.0031^{*} \\
(0.055)\end{array}$ & $\begin{array}{l}-0.0027^{*} \\
(0.078)\end{array}$ & $\begin{array}{l}-0.0031 \\
(0.120)\end{array}$ & .. & .. & .. \\
\hline$T C_{U K, j}$ & .. &.. & .. & $\begin{array}{l}-0.0071^{* *} \\
(0.049)\end{array}$ & $\begin{array}{l}-0.0063 * \\
(0.067)\end{array}$ & $\begin{array}{l}-0.0071 \\
(0.119)\end{array}$ \\
\hline$T C_{U S, j}$ & .. & .. & .. & $\begin{array}{l}0.0870 * \\
(0.061)\end{array}$ & $\begin{array}{r}0.0721 \\
(0.107)\end{array}$ & $\begin{array}{c}0.0870 \\
(0.119)\end{array}$ \\
\hline$T C_{C A N, J}$ & .. & .. & .. & $\begin{array}{l}-0.0482 * \\
(0.057)\end{array}$ & $\begin{array}{l}-0.0410 * \\
(0.096)\end{array}$ & $\begin{array}{l}-0.0482 \\
(0.117)\end{array}$ \\
\hline$R E R_{j}$ & $\begin{array}{l}0.0005^{* * *} \\
(0.000)\end{array}$ & $\begin{array}{l}0.0004 * * * \\
(0.001)\end{array}$ & $\begin{array}{l}0.0005^{* * *} \\
(0.000)\end{array}$ & .. & .. & .. \\
\hline$R E R_{U k, j}$ & .. & .. & .. & $\begin{array}{l}-0.0457 \\
(0.140)\end{array}$ & $\begin{array}{l}-0.0502 * \\
(0.090)\end{array}$ & $\begin{array}{l}-0.0457 \\
(0.183)\end{array}$ \\
\hline$R E R_{U S, j}$ & .. & .. & .. & $\begin{array}{l}-0.1000 \\
(0.111)\end{array}$ & $\begin{array}{l}-0.0734 \\
(0.214)\end{array}$ & $\begin{array}{l}-0.1000 \\
(0.138)\end{array}$ \\
\hline$R E R_{C A N, j}$ & .. & .. & .. & $\begin{array}{l}0.2745^{* * *} * \\
(0.000)\end{array}$ & $\begin{array}{l}0.2558 * * * \\
(0.000)\end{array}$ & $\begin{array}{l}0.2745^{* * *} \\
(0.000)\end{array}$ \\
\hline$I N V_{j}$ & $\begin{array}{l}-0.0012 \\
(0.306)\end{array}$ & $\begin{array}{l}-0.0001 \\
(0.957)\end{array}$ & $\begin{array}{l}-0.0012 \\
(0.395)\end{array}$ & $\begin{array}{l}-0.0003 \\
(0.757)\end{array}$ & $\begin{array}{c}0.0008 \\
(0.367)\end{array}$ & $\begin{array}{l}-0.0003 \\
(0.817)\end{array}$ \\
\hline $\operatorname{GCONS}_{j}$ & $\begin{array}{l}-0.0067 * \\
(0.067)\end{array}$ & $\begin{array}{l}-0.0064 * \\
(0.058)\end{array}$ & $\begin{array}{l}-0.0068 * \\
(0.093)\end{array}$ & $\begin{array}{l}-0.0090^{* *} \\
(0.020)\end{array}$ & $\begin{array}{l}-0.0075^{* *} \\
(0.033)\end{array}$ & $\begin{array}{l}-0.0090^{* *} \\
(0.032)\end{array}$ \\
\hline TRADEOPEN $_{j}$ & $\begin{array}{l}-0.0014 * * * \\
(0.000)\end{array}$ & $\begin{array}{l}-0.0014 * * * \\
(0.000)\end{array}$ & $\begin{array}{l}-0.0014 * * * \\
(0.000)\end{array}$ & $\begin{array}{l}-0.0013 * * * \\
(0.000)\end{array}$ & $\begin{array}{l}-0.0012 * * * \\
(0.000)\end{array}$ & $\begin{array}{l}-0.0013 * * * \\
(0.000)\end{array}$ \\
\hline POPDENS $_{j}$ & $\begin{array}{l}1.7766^{* * * *} \\
(0.000)\end{array}$ & $\begin{array}{l}1.1103 * * * \\
(0.000)\end{array}$ & $\begin{array}{l}1.7766^{* * * *} \\
(0.000)\end{array}$ & $\begin{array}{l}1.7239 \text { *** } \\
(0.000)\end{array}$ & $\begin{array}{l}1.1838 * * * \\
(0.000)\end{array}$ & $\begin{array}{l}1.7239 * * * \\
(0.000)\end{array}$ \\
\hline CREDITPS $_{j}$ & $\begin{array}{l}0.0027 * * \\
(0.034)\end{array}$ & $\begin{array}{l}0.0030 * * * \\
(0.007)\end{array}$ & $\begin{array}{l}0.0027 * \\
(0.085)\end{array}$ & $\begin{array}{l}0.0037 * * * \\
(0.004)\end{array}$ & $\begin{array}{l}0.0030 * * * \\
(0.006)\end{array}$ & $\begin{array}{l}0.0037 * * \\
(0.023)\end{array}$ \\
\hline EMPLINDEX $_{j}$ & $\begin{array}{l}-0.6496^{* * *} \\
(0.000)\end{array}$ & $\begin{array}{l}-0.4081^{* * *} \\
(0.000)\end{array}$ & $\begin{array}{l}-0.6496 * * * \\
(0.000)\end{array}$ & $\begin{array}{l}-0.6216^{* * *} \\
(0.000)\end{array}$ & $\begin{array}{l}-0.4323 * * * \\
(0.000)\end{array}$ & $\begin{array}{l}-0.6216^{* * * *} \\
(0.000)\end{array}$ \\
\hline $\operatorname{COLSPAIN}_{j}$ & $\begin{array}{l}13.0408^{* * *} \\
(0.000)\end{array}$ & .. & $\begin{array}{l}13.0408 * * * \\
(0.000)\end{array}$ & $\begin{array}{l}12.377 * * * \\
(0.000)\end{array}$ & $\begin{array}{l}19.1195^{* * * *} \\
(0.001)\end{array}$ & $\begin{array}{l}12.3768 * * * \\
(0.000)\end{array}$ \\
\hline $\mathrm{COLUK}_{j}$ & $\begin{array}{l}-5.3441 * * * \\
(0.000)\end{array}$ & $\begin{array}{c}-11.3570 * * * \\
(0.000)\end{array}$ & $\begin{array}{l}-5.3441 * * * \\
(0.000)\end{array}$ & $\begin{array}{l}-5.1121 * * * \\
(0.000)\end{array}$ & $\begin{array}{l}6.9959^{*} \\
(0.053)\end{array}$ & $\begin{array}{l}-5.1120 * * * \\
(0.000)\end{array}$ \\
\hline$E V I D_{j}$ & $\begin{array}{l}-4.7653^{* * *} \\
(0.000)\end{array}$ & $\begin{array}{l}-2.9667 * * * \\
(0.000)\end{array}$ & $\begin{array}{l}-4.7653 * * * \\
(0.000)\end{array}$ & $\begin{array}{l}-4.5567 * * * \\
(0.000)\end{array}$ & $\begin{array}{l}-3.1437 * * * \\
(0.000)\end{array}$ & $\begin{array}{l}-4.5567 * * * \\
(0.000)\end{array}$ \\
\hline$A I D S_{j}$ & $\begin{array}{l}-0.0131 * * * \\
(0.000)\end{array}$ & $\begin{array}{l}-0.0076 * * * \\
(0.001)\end{array}$ & $\begin{array}{l}-0.0131 * * * \\
(0.000)\end{array}$ & $\begin{array}{l}-0.0121 * * * \\
(0.000)\end{array}$ & $\begin{array}{l}-0.0080 * * * \\
(0.000)\end{array}$ & $\begin{array}{l}-0.0121 \text { *** } \\
(0.000)\end{array}$ \\
\hline$T_{U B E R_{j}}$ & $\begin{array}{l}-0.0004 \\
(0.755)\end{array}$ & $\begin{array}{c}0.0003 \\
(0.760)\end{array}$ & $\begin{array}{l}-0.0004 \\
(0.801)\end{array}$ & $\begin{array}{c}0.0003 \\
(0.797)\end{array}$ & $\begin{array}{l}0.00004 \\
(0.970)\end{array}$ & $\begin{array}{c}0.0003 \\
(0.840)\end{array}$ \\
\hline$T E L_{j}$ & $\begin{array}{l}0.1576^{* * *} \\
(0.000)\end{array}$ & $\begin{array}{l}0.0984 * * * \\
(0.000)\end{array}$ & $\begin{array}{l}0.1575^{* * *} \\
(0.000)\end{array}$ & $\begin{array}{l}0.1507 * * * \\
(0.000)\end{array}$ & $\begin{array}{l}0.1030 * * * \\
(0.000)\end{array}$ & $\begin{array}{l}0.1507 * * * \\
(0.000)\end{array}$ \\
\hline
\end{tabular}




\begin{tabular}{|c|c|c|c|c|c|c|}
\hline & \multicolumn{3}{|c|}{ Model specification A } & \multicolumn{3}{|c|}{ Model specification B } \\
\hline & $\mathrm{OLS}^{\mathrm{c}}$ & $\mathrm{GLS}^{\mathrm{d}}$ & Random Effects & $\mathrm{OLS}^{\mathrm{c}}$ & $\mathrm{GLS}^{\mathrm{d}}$ & Random Effects \\
\hline Number of observations & 80 & 80 & 80 & 80 & 80 & 80 \\
\hline R-square & 0.98 & .. & 0.98 & 0.98 & .. & 0.98 \\
\hline Wald statistic & $\begin{array}{r}54067.0 \\
(0.000)\end{array}$ & $\begin{array}{l}3765.8 \\
(0.000)\end{array}$ & $\begin{array}{l}2769.1 \\
\quad(0.000)\end{array}$ & $\begin{array}{l}5255.5 \\
(0.000)\end{array}$ & $\begin{array}{l}5309.9 \\
(0.000)\end{array}$ & $\begin{array}{r}3177.4 \\
(0.000)\end{array}$ \\
\hline \multicolumn{7}{|c|}{$\begin{array}{l}\text { Hausman test (fixed effect vs. } \\
\text { random effects) }\end{array}$} \\
\hline Chi-squared test statistic & .. & .. & $\begin{array}{l}15.54 \\
(0.557)\end{array}$ &.$\cdot$ &.$\cdot$ & $\begin{array}{l}11.61 \\
(0.901)\end{array}$ \\
\hline
\end{tabular}

Source: Author's estimations.

Note: The pooled ols estimator is an unweighted average of the fixed effects (FE) and between effects (BE) estimator, while the re estimator is a matrix-weighted average of the $\mathrm{FE}$ and $\mathrm{BE}$ estimators. The re estimator converges towards the ols estimator as the variance of the country-specific random error term converges towards zero and the two are exactly identical when the variance of the country-specific random error term is zero.

a Including time dummies in all regressions; p-values in parentheses.

b For a definition of this variable and others used in the model, see section III.

Ordinary least squares estimation with heteroskedasticity-corrected standard errors.

d Generalized least squares estimation allowing for cross-sectional heteroskedasticity only.

$*=$ significant at the $10 \%$ level, $* *=$ significant at the $5 \%$ level, $* * *=$ significant at the $1 \%$ level.

..$=$ not included, not applicable or dropped from the regression due to collinearity.

significance regardless of the estimation method used. ${ }^{11}$ This corroborates previous empirical analysis by the International Monetary Fund (2004), which noted that during the period 1990-2001 the English-speaking member countries of CARICOM lost world market share to newly emerging, lower-cost tourism destinations elsewhere in the Caribbean. ${ }^{12}$ In 2005, the CARICOM Caribbean Trade and Investment Report 2005 noted that the Organization

\footnotetext{
11 An argument can be made that physical size matters and that it is easier for large countries like the Dominican Republic to raise their share of world tourism arrivals by tapping economies of scale and longer tourism life cycles. In order to check for the effect of size on competitiveness, table 4 was re-estimated under the RE method without the colonial dummy variables but with a dummy variable for size included. The large countries in the sample are Belize, the Dominican Republic and Suriname. Results were broadly similar except for the signs on the health variables (which were in the wrong direction), while the coefficient on investment was positive and significant at a $10 \%$ level. The coefficient on the dummy variable for size was significant, large and positive. However, when the colonial dummy variables were added, the coefficient on the Spanish dummy variable remained positive, large and significant, while the coefficient on the size dummy variable turned negative, albeit significant. The competitive advantage of the Spanish-speaking Caribbean thus does not seem to be driven by size alone.

12 The same report highlighted that the loss in caricom and in the Eastern Caribbean Currency Union of market share to other Caribbean destinations during the period 1995-2001 might be associated with a decline in price and/or non-price competitiveness. Non-price factors include product design, packaging, quality of service, reliability of supplies, after-sales service, distribution networks, marketing and market intelligence, and air access.
}

of Eastern Caribbean States tourism sector ranked very low in competitiveness and was continuing to lose market share to the Spanish-speaking Caribbean (CARICOM, 2005). There is also evidence at the $1 \%$ level of significance that the availability of technological facilities, as proxied by the number of telephone mainlines in use (TEL), fosters tourism competitiveness. Lastly, the positive and highly significant estimated coefficient on the population density variable (POPDENSITY) could indicate that the availability of urban facilities attracts certain types of tourists to the region.

At the same time, the impact of government consumption (GCONS) on tourism competitiveness is found to be negative, but only at the $10 \%$ level of significance using the three estimation methods in model specification A. In the case of domestic credit to the private sector (CREDITPS), it was found that such credit stimulates tourism competitiveness at different levels of significance depending on the estimation method used.

As regards the time dummies included in the regression (not shown), the one for 2001 exhibited a negative and highly significant estimated parameter signalling the detrimental impact of the September 2001 attacks in the United States. Perhaps more importantly, there is strong evidence to suggest that the Caribbean lost competitiveness in the period 2001-2005 relative to 1995 , given the large, negative and statistically significant estimated coefficients on these time dummy variables 
(significant at the $1 \%$ level using either the oLs or the GLS estimation method). This is a worrying outcome.

All in all, two surprising results stand out. First, there is no evidence that higher levels of investment $(I N V)$ in the Caribbean will benefit the tourism sector in terms of competitiveness. Second, real income growth in the source markets $(Y)$ is not statistically significant in affecting tourism competitiveness in the region. Thus, real income growth in the source markets on average does not seem to impact on tourism competitiveness at all. It is possible, however, that the inclusion of the time dummy variables is capturing the impact of world business economic cycles, which are strongly correlated with real income growth in countries such as Canada, the United Kingdom and the United States, and that such inclusion is rendering the income variables insignificant due to collinearity.

To address this latter issue, another regression specification (в) was estimated disaggregating both the income growth variable $(Y)$ and the real exchange rate variable $(R E R)$ used in specification A into their individual source market components. Accordingly, variable $Y$ was disaggregated into real income growth in Canada $\left(Y_{C A N}\right)$, the United Kingdom $\left(Y_{U K}\right)$ and the United States $\left(Y_{U S}\right)$. However, since the series on real income growth in the first two countries failed to pass the Levin-Lin-Chu test for stationarity, only real income growth in the United States was included, along with real income growth in the world $\left(Y_{W}\right)$, as the two series showed stationary behaviour. The latter variable was used as a proxy variable for real income growth in Canada and the United Kingdom. The simple correlation coefficient between $Y_{W}$ and $Y_{C A N}$ and between $Y_{W}$ and $Y_{U K}$ is 0.54 in both cases, and it is statistically significant at the $5 \%$ level. By the same token, the real exchange rate index $(R E R)$ was disaggregated into the three bilateral real exchange rates between the local currency and the currency of each source market $\left(R E R_{C A N}, R E R_{U K}, R E R_{U S}\right)$, which were included in the regression specification. In addition, three transport cost variables were included —one for each source market $\left(T C_{C A N}, T C_{U K}, T C_{U S}\right)$ - combining oil price trends and the distance between the source and destination markets (see table 3 for details), in place of the single proxy variable GPOIL used in specification A. The results are shown in table 4 .

As can be seen, there is strong evidence ${ }^{13}$ that tourism competitiveness in the Caribbean is significantly (at the $1 \%$ level) positively correlated with population density

13 The coefficients are significant across all three estimation methods at levels of significance of $10 \%$ or less.
(POPDENS) and technological facilities (TEL) and negatively correlated with openness to trade (TRADEOPEN), rigidities in the labour market (EMPINDEX), vulnerability to natural disasters (EVID) and HIV/AIDS prevalence (AIDS). All these results are consistent with the previous findings from the estimation of specification A using the OLS, GLS or RE methods. The high positive and statistically significant impact of the former Spanish colony dummy variable (COLSPAIN) is also confirmed. However, the negative impact found in specification A for the former British colonies (COLUK) is corroborated only using the OLS and RE model estimations, but not when applying the GLS method (actually, the sign of the estimated coefficient is positive and significant at the $10 \%$ level). In addition, government consumption (GCONS) is found to negatively affect tourism competitiveness at the 5\% level of significance (at the $10 \%$ level in specification A), whereas the surprising result found in the estimation of specification A about the insignificant effect of investment (INV) on tourism competitiveness is confirmed. Notwithstanding, under specification B most of the time dummy variables are no longer significant except for the time dummy for year 2004 (results not shown in table 4), which showed a negative estimated coefficient. This may be related to the impacts of hurricanes Jeanne, Ivan, Frances and Charley in that year. The year 2004 was marked by an unusually active hurricane season with all four hurricanes striking within a two-month period. ${ }^{14}$

Perhaps more interesting are the results that differ from the previous estimation, i.e. specification A. There is partial evidence from the oLS and GLS estimations that both real income growth in the United States and in the world - a rough proxy for income growth rates in Canada and the United Kingdom, which exhibited nonstationary behaviour - raise tourism competitiveness in the Caribbean, though just at the $10 \%$ level of significance. In addition, there is evidence to suggest that British and Canadian tourists are more sensitive to increases in transport costs induced by higher oil prices than are their American counterparts. This is revealed by the negative coefficients associated with $T C_{C A N}$ and $T C_{U K}$ in both the oLS and the GLS estimations, which are statistically different from zero at the $10 \%$ level of significance (at the 5\% level of significance in the case of $T C_{U K}$ using the oLS method). The latter result does

\footnotetext{
14 The Economic Commission for Latin America and the Caribbean (ECLAC) estimated losses to have been more than US\$ 2.2 billion in 2004 from the hurricanes, which struck four countries (Bahamas, Dominican Republic, Grenada and Jamaica), three of which are included in our sample.
} 
not hold, however, using the RE estimation method. Thus, increases in transport costs would deter British and Canadian tourists from travelling to the Caribbean and induce them to shift to relatively less-distant nonCaribbean destinations (such as Spain or the United States) with lower airfares.

By the same token, there is some indication that higher transport costs resulting from higher oil prices may actually induce American tourists to switch to nearer, Caribbean destinations relative to more-distant, non-Caribbean countries, as revealed by the positive estimated coefficients associated with $T C_{U S}$ (though this coefficient is significant only at the $10 \%$ level in the oLs estimation method). Canadian tourists seem to be the most price-sensitive as compared with their American and British counterparts. Indeed, it is found that a real appreciation of the local currency relative to the Canadian currency has a large and significant (at the $1 \%$ level) negative impact on tourism competitiveness under all three estimation methods.

In contrast, British and, especially, American tourists seem to be price-insensitive. ${ }^{15}$ This could reflect differences in the income segments of tourists targeted by the destination across its source markets. Canadian travellers to the Caribbean tend to be lowbudget travellers who target the low-cost end of the tourism market and concentrate mostly on the Spanishspeaking Caribbean with its range of low-to-mediumbudget accommodation. In fact, some $60 \%$ of Canadians travelling to the Caribbean end up in either Cuba or the Dominican Republic, according to the Caribbean Tourism Organization. Dependency on the Canadian source market is generally low in the non-Spanish-speaking Caribbean (it is less than $10 \%$ for most countries, save Guyana, Haiti and the Turks and Caicos) (ECLAC, 2008b). Conversely, British tourists to the Caribbean are more likely to be upper-income travellers targeting the high end of the market, with Barbados as their destination of choice. Of course, low-budget travellers are expected to be far more price-sensitive than travellers from the upper end of the market.

\section{Robustness checks}

Two robustness checks are now performed on the results. The first is to control for potential endogeneity between some explanatory variables and the error disturbance term. Under the standard assumptions of the classical

15 Although the negative estimated coefficient associated with $T C_{U K}$ is significant at the $10 \%$ level in the gls estimation method. linear regression model, estimation by ordinary least squares yields unbiased and efficient estimators for the parameters on the explanatory variables as long as there is no contemporaneous correlation between the explanatory variables and the error disturbance term and such explanatory variables are determined exogenously to the estimation model. However, such an assumption is usually violated if there are omitted variables from the model that turn out to be contemporaneously correlated with the explanatory variables included in the model and/or if the dependent variable is thought to contemporaneously influence the explanatory variables. To address such sources of potential endogeneity, models A and B again are estimated using one-period-lagged values for the explanatory variables that are time-variant within a given panel and that can potentially be influenced contemporaneously by the dependent variable. Such explanatory variables are: the bilateral real exchange rates, trade openness, domestic credit to the private sector, the share of gross fixed capital formation in GDP and the share of government final consumption expenditure in GDP. The remaining time-variant variables within the panels, namely the transport costs (which vary with growth in oil prices only), the growth in real income in the source markets and population density are taken to satisfy the condition of exogeneity. It is reasonable to argue that growth in oil prices and income growth rates in the source markets are unlikely to be correlated with the determinants of competitiveness specific to each Caribbean tourism destination. Oil prices are set by world demand and world supply forces that Caribbean destinations take as exogenous, while income growth in Canada, the United Kingdom and the United States is unlikely to be influenced or correlated with Caribbeanspecific competitiveness conditions. Population density for a given destination is likely to change slowly over a 10-year period (as land size is fixed), while changes in population are slow and determined exogenously to tourism competitiveness conditions.

Table 5 reports the results when the potentially endogenous explanatory variables are lagged by one year.

Comparing table 4 with table 5 , it can be seen from model A that the results remain broadly robust. The main differences are that, under model $\mathrm{B}$, the evidence that appreciation of the local currency relative to the Canadian currency significantly undermines tourism competitiveness of the local destination vanishes and, for the first time, it is found that increases in gross fixed capital formation in GDP could significantly raise tourism competitiveness (using the GLS method). 
TABLE 5

\section{Regression results ${ }^{\mathbf{a}}$}

(Dependent variable $S_{i j}{ }^{b}$; sample 1996-2006; annual frequency)

\begin{tabular}{|c|c|c|c|c|c|c|}
\hline & \multicolumn{3}{|c|}{ Model specification A } & \multicolumn{3}{|c|}{ Model specification B } \\
\hline & $\mathrm{OLS}^{\mathrm{c}}$ & $\mathrm{GLS}^{\mathrm{d}}$ & Random Effects & $\mathrm{OLS}^{\mathrm{c}}$ & $\mathrm{GLS}^{\mathrm{d}}$ & Random Effects \\
\hline$Y_{j}$ & $\begin{array}{l}-0.0007 \\
(0.234)\end{array}$ & $\begin{array}{c}0.0001 \\
(0.795)\end{array}$ & $\begin{array}{l}-0.0007 \\
(0.335)\end{array}$ & .. & .. & .. \\
\hline$Y_{U S}$ &.. &.. &.. & $\begin{array}{c}0.2569 \\
(0.109)\end{array}$ & $\begin{array}{r}0.2347 \\
(0.130)\end{array}$ & $\begin{array}{c}0.2569 \\
(0.259)\end{array}$ \\
\hline$Y_{W}$ & .. & .. & .. & $\begin{array}{l}1.1187 * \\
(0.067)\end{array}$ & $\begin{array}{c}0.9221 \\
(0.119)\end{array}$ & $\begin{array}{l}1.1187 \\
(0.196)\end{array}$ \\
\hline GPOIL $_{j}$ & $\begin{array}{l}-0.0014 * * * \\
(0.000)\end{array}$ & $\begin{array}{l}-0.0011 * * * \\
(0.000)\end{array}$ & $\begin{array}{l}-0.0014 * * * \\
(0.001)\end{array}$ & .. &.. & .. \\
\hline$T C_{U K, j}$ &.. &.. &.. & $\begin{array}{l}-0.0054^{*} \\
(0.067)\end{array}$ & $\begin{array}{l}-0.0042 \\
(0.143)\end{array}$ & $\begin{array}{l}-0.0054 \\
(0.182)\end{array}$ \\
\hline$T C_{U S, j}$ & .. & .. & .. & $\begin{array}{l}0.0662 * \\
(0.078)\end{array}$ & $\begin{array}{c}0.0496 \\
(0.168)\end{array}$ & $\begin{array}{c}0.0662 \\
(0.184)\end{array}$ \\
\hline$T C_{C A N, j}$ & .. & .. & .. & $\begin{array}{l}-0.0387 * \\
(0.057)\end{array}$ & $\begin{array}{l}-0.0300 \\
(0.125)\end{array}$ & $\begin{array}{l}-0.0387 \\
(0.160)\end{array}$ \\
\hline Lagged $R E R_{j}$ & $\begin{array}{l}0.0005^{* * * *} \\
(0.000)\end{array}$ & $\begin{array}{l}0.0003 * \\
(0.014)\end{array}$ & $\begin{array}{l}0.0004 * * * \\
(0.000)\end{array}$ &.. &.. &.. \\
\hline Lagged $R E R_{U K, j}$ & .. &.. & .. & $\begin{array}{c}0.0041 \\
(0.894)\end{array}$ & $\begin{array}{l}-0.0294 \\
(0.275)\end{array}$ & $\begin{array}{c}0.0041 \\
(0.902)\end{array}$ \\
\hline Lagged $R E R_{U S, j}$ & .. & .. & .. & $\begin{array}{l}-0.0118 \\
(0.861)\end{array}$ & $\begin{array}{c}0.0206 \\
(0.716)\end{array}$ & $\begin{array}{l}-0.0118 \\
(0.861)\end{array}$ \\
\hline Lagged $R E R_{C A N, j}$ & .. & .. & .. & $\begin{array}{c}0.0539 \\
(0.521)\end{array}$ & $\begin{array}{l}0.0783 \\
(0.263)\end{array}$ & $\begin{array}{c}0.0539 \\
(0.513)\end{array}$ \\
\hline Lagged $I N V_{j}$ & $\begin{array}{c}0.0011 \\
(0.384)\end{array}$ & $\begin{array}{c}0.0023 \\
(0.957)\end{array}$ & $\begin{array}{c}0.0011 \\
(0.499)\end{array}$ & $\begin{array}{l}0.0015 \\
(0.184)\end{array}$ & $\begin{array}{l}0.0028^{* * *} \\
(0.002)\end{array}$ & $\begin{array}{l}0.0015 \\
(0.343)\end{array}$ \\
\hline${\text { Lagged } G C O N S_{j}}$ & $\begin{array}{l}-0.0088^{* * * *} \\
(0.009)\end{array}$ & $\begin{array}{l}-0.0079 * * \\
(0.013)\end{array}$ & $\begin{array}{l}-0.0088^{* * *} \\
(0.027)\end{array}$ & $\begin{array}{l}-0.0110^{* * * *} \\
(0.000)\end{array}$ & $\begin{array}{l}-0.0077 * * * \\
(0.002)\end{array}$ & $\begin{array}{l}-0.0110^{* * *} \\
(0.003)\end{array}$ \\
\hline Lagged TRADEOPEN $N_{j}$ & $\begin{array}{l}-0.0011 * * * \\
(0.000)\end{array}$ & $\begin{array}{l}-0.0011 * * * \\
(0.000)\end{array}$ & $\begin{array}{l}-0.0011 * * * \\
(0.000)\end{array}$ & $\begin{array}{l}-0.0010 * * * \\
(0.000)\end{array}$ & $\begin{array}{l}-0.0010 * * * \\
(0.000)\end{array}$ & $\begin{array}{l}-0.0010^{* * * *} \\
(0.000)\end{array}$ \\
\hline POPDENS $_{j}$ & $\begin{array}{l}1.5940 * * * \\
(0.000)\end{array}$ & $\begin{array}{l}1.2653 * * * \\
(0.000)\end{array}$ & $\begin{array}{l}1.5940 * * * \\
(0.000)\end{array}$ & $\begin{array}{l}1.6839 * * * \\
(0.000)\end{array}$ & $\begin{array}{l}0.9991 * * * \\
(0.000)\end{array}$ & $\begin{array}{l}1.6839 * * * \\
(0.000)\end{array}$ \\
\hline${\text { Lagged } C R E D I T P S_{j}}$ & $\begin{array}{l}0.0029^{* *} \\
(0.019)\end{array}$ & $\begin{array}{l}0.0026^{* *} \\
(0.020)\end{array}$ & $\begin{array}{l}0.0029 * * \\
(0.044)\end{array}$ & $\begin{array}{l}0.0031^{* *} \\
(0.005)\end{array}$ & $\begin{array}{l}0.0029 * * * \\
(0.002)\end{array}$ & $\begin{array}{l}0.0031^{* *} \\
(0.028)\end{array}$ \\
\hline EMPLINDEX $_{j}$ & $\begin{array}{l}-0.5875^{* * * *} \\
(0.000)\end{array}$ & $\begin{array}{l}-0.4681 * * * \\
(0.000)\end{array}$ & $\begin{array}{l}-0.5875^{* * *} \\
(0.000)\end{array}$ & $\begin{array}{l}-0.6140 * * * \\
(0.000)\end{array}$ & $\begin{array}{l}-0.3689 * * * \\
(0.000)\end{array}$ & $\begin{array}{l}-0.6140 * * * \\
(0.000)\end{array}$ \\
\hline $\operatorname{COLSPAIN~}_{j}$ & $\begin{array}{l}16.6041 * * * \\
(0.000)\end{array}$ & .. & $\begin{array}{l}16.6041 * * * \\
(0.000)\end{array}$ & $\begin{array}{l}12.437 * * * \\
(0.000)\end{array}$ &.. & $\begin{array}{l}12.4368^{* * * *} \\
(0.000)\end{array}$ \\
\hline $\mathrm{COLUK}_{j}$ & .. & $\begin{array}{l}-13.2328 * * * \\
(0.000)\end{array}$ & .. & $\begin{array}{l}-4.9507 * * * \\
(0.000)\end{array}$ & $\begin{array}{c}-10.3839 * * * \\
(0.000)\end{array}$ & $\begin{array}{l}-4.9507 * * * \\
(0.000)\end{array}$ \\
\hline$E V I D_{j}$ & $\begin{array}{l}-4.2998 * * * \\
(0.000)\end{array}$ & $\begin{array}{l}-3.4032 * * * \\
(0.000)\end{array}$ & $\begin{array}{l}-4.2998 * * * \\
(0.000)\end{array}$ & $\begin{array}{l}-4.4926 * * * \\
(0.000)\end{array}$ & $\begin{array}{l}-2.6660 * * * \\
(0.000)\end{array}$ & $\begin{array}{l}-4.4926 * * * \\
(0.000)\end{array}$ \\
\hline$A I D S_{j}$ & $\begin{array}{l}-0.0117 * * * \\
(0.000)\end{array}$ & $\begin{array}{l}-0.0089 * * * \\
(0.000)\end{array}$ & $\begin{array}{l}-0.0117 * * * \\
(0.000)\end{array}$ & $\begin{array}{l}-0.0122 * * * \\
(0.000)\end{array}$ & $\begin{array}{l}-0.0067 * * * \\
(0.000)\end{array}$ & $\begin{array}{l}-0.0122 * * * \\
(0.000)\end{array}$ \\
\hline$T U B E R_{j}$ & $\begin{array}{l}-0.0004 \\
(0.703)\end{array}$ & $\begin{array}{l}-0.0005 \\
(0.611)\end{array}$ & $\begin{array}{l}-0.0004 \\
(0.756)\end{array}$ & $\begin{array}{l}-0.0007 \\
(0.519)\end{array}$ & $\begin{array}{l}-0.0005 \\
(0.575)\end{array}$ & $\begin{array}{l}-0.0007 \\
(0.616)\end{array}$ \\
\hline$T E L_{j}$ & $\begin{array}{l}0.1410^{* * * *} \\
(0.000)\end{array}$ & $\begin{array}{l}0.1101 * * * \\
(0.000)\end{array}$ & $\begin{array}{l}0.1410^{* * *} \\
(0.000)\end{array}$ & $\begin{array}{l}0.1464^{* * * *} \\
(0.000)\end{array}$ & $\begin{array}{l}0.0852 * * * \\
(0.000)\end{array}$ & $\begin{array}{l}0.1464 * * * \\
(0.000)\end{array}$ \\
\hline Number of observations & 72 & 72 & 72 & 80 & 80 & 80 \\
\hline $\mathrm{R}$-square & 0.98 & .. & 0.98 & 0.98 & .. & 0.98 \\
\hline Wald statistic & $\begin{array}{c}4294.2 \\
(0.000)\end{array}$ & $\begin{array}{r}4266.5 \\
(0.000)\end{array}$ & $\begin{array}{l}2938.0 \\
(0.000)\end{array}$ & $\begin{array}{c}6176.0 \\
(0.000)\end{array}$ & $\begin{array}{c}4368.2 \\
(0.000)\end{array}$ & $\begin{array}{l}3512.8 \\
(0.000)\end{array}$ \\
\hline
\end{tabular}

Source: Author's estimations.

Note: The Hausman tests failed and thus are not reported.

a Including time dummies in all regressions. The estimated coefficients of the dummies on years 2004 and 2005 were negative and significant at a $10 \%$ level in all three cases in model A. The estimated coefficient on year 2004 was negative and significant at a 10\% level in two cases in model B. $P$-values in parentheses.

b For a definition of this variable and others used in the model, see section III.

c Ordinary least squares estimation with heteroskedasticity-corrected standard errors.

d Generalized least squares estimation allowing for cross-sectional heteroskedasticity only.

$*$ = significant at the $10 \%$ level, $* *=$ significant at the 5\% level, $* * *=$ significant at the $1 \%$ level.

..$=$ not included, not applicable or dropped from the regression due to collinearity. 
A second robustness check consists of testing for the sensitivity of the results to the potential presence of influential observations in the data. The figure below plots leverage points against the normalized standard residuals when estimating models $\mathrm{A}$ and $\mathrm{B}$ by the oLs method.

FIGURE1

\section{Leverage versus normalized standard residuals plots}

Model A

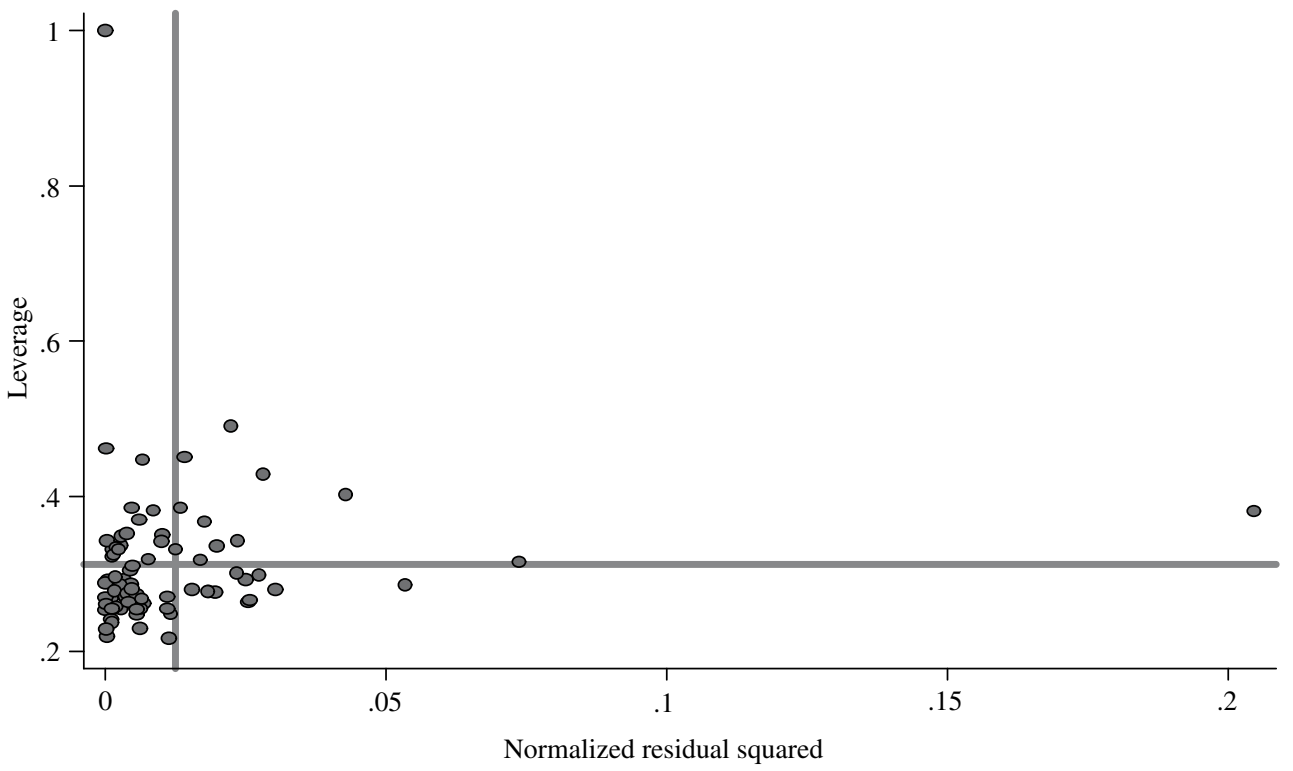

Model B

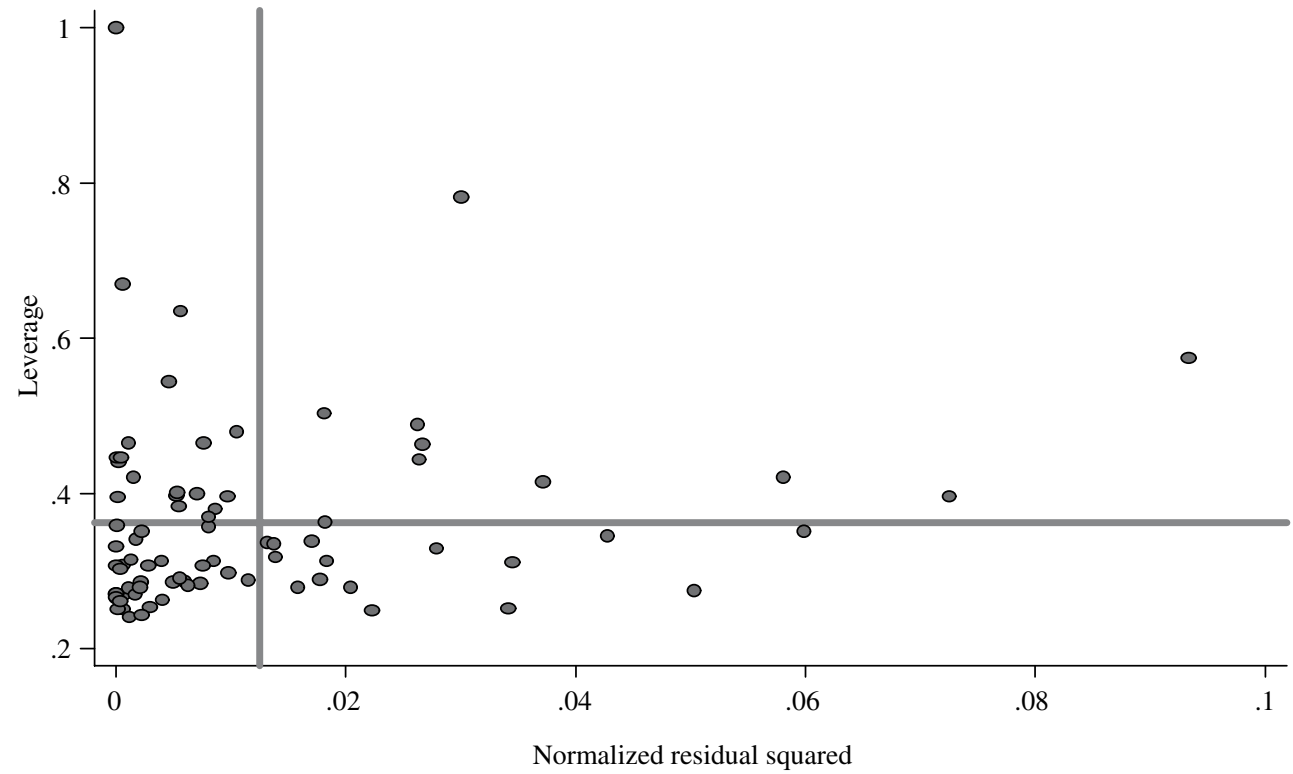

Source: Prepared by the author.

Note: These are obtained by estimating models A and B as described in table 4 using the ols method only. 
Points in the upper left-hand corner signal the presence of leverage points, ${ }^{16}$ while points in the lower right corner signal unusually high normalized standard residuals. From these plots, visually there are several observations that can potentially be influential (high leverage and/or high standardized residuals). To control for influential observations, the estimations are carried out as in table 4 , this time omitting variables with a Cook's statistic that exceeds the cut-off value of $4 / n$, where $n$ is the sample size (in this case 80), as is standard procedure. ${ }^{17}$ The results are reported in table 6 .

Comparing table 6 with table 4 , it can be seen that the results are fairly robust using both models. Results from model specification B show some slight differences as compared with table 4, though. After controlling for influential observations, there is partial evidence that increases in gross fixed capital formation in GDP can benefit tourism competitiveness (using the GLS method). In addition, there is evidence that growth in incomes in the United States and worldwide results in a greater share of tourists landing in the Caribbean. Both income growth variables are significant at either the $10 \%$ or the $5 \%$ level.

In table 7 , both endogeneity and influential observations are controlled for as compared with table 4. Doing so yields a set of robust results. There is firm evidence that tourism competitiveness in the Caribbean is significantly hampered by growth in oil prices, increases in government final consumption expenditure in GDP, trade openness, rigidity in employment and labour market conditions, exposure to natural disasters and health concerns (such as HIV/AIDS) in the destination country. At the same time, competitiveness benefits from increases in gross fixed capital formation in GDP, credit support to the private sector, population density and better infrastructure as mirrored by increases in the number of telephone mainlines in the destination country. There is also firm evidence that Spanish-speaking countries have

\footnotetext{
16 According to Kennedy (2007), there are two kinds of outliers that may have a strong influence on estimates produced by the oLS method. The first type of outlier consists of observations with unusually large errors, and the second type consists of leverage points, that is, observations with unusual values on an explanatory variable. What should be controlled for are not outliers per se but rather influential observations, i.e. outliers that have a strong influence on oLs estimates. Such influential observations are data points whose removal from the estimation would dramatically alter the coefficients obtained from the regression model.

17 The ols method is used to estimate models A and B in table 4 and to calculate the Cook's statistic for these two models respectively. Then, table 4 is estimated again by omitting variables with a Cook's statistic exceeding $0.05(4 / 80)$. For a definition and explanation of the Cook's statistic, see Cook (1977).
}

a comparative advantage relative to the English-speaking countries in the Caribbean. There is partial evidence that British tourists may be price-insensitive in the sense that a real appreciation of the destination currency relative to the pound sterling does not deter them from spending their holidays in the Caribbean. In addition, there is partial evidence to suggest that Canadian tourists are more price-sensitive relative to American and British tourists and that a real appreciation of the local destination currency relative to the Canadian dollar induces them to substitute with non-Caribbean destinations. However, there is no evidence from model B that income growth in source markets matters or that geographical distance by source market matters as opposed to growth in oil prices alone. No evidence is found from model A that the weighted average of bilateral real exchange rates exerts a significant impact on tourism competitiveness. These three findings are inconsistent with some of the previous findings shown in tables 4 - 6 .

Summing up the results from tables 5 and 7 , the robustness checks actually enhance the significance of most of the explanatory variables used and with signs in the expected direction. However, in the case of the income growth variables, real exchange rates and transport costs by source market, the evidence obtained is mixed.

Based on the RE estimation under model $\mathrm{A}$ in table $7,{ }^{18}$ in terms of the impacts that are significant at least at a $1 \%$ level, we find that:

(i) An increase in the rate of growth of oil prices leads to a fall in the share of world outbound American, British and Canadian tourists travelling to the Caribbean. This is in line with the notion that price and cost competitiveness are important elements of competitiveness (Craigwell, 2007). Faster oil price increases impact on the costs of air travel and can result in airlines reducing the frequency of flights to the Caribbean, thereby reducing the attractiveness of the region as a destination (Odle, 2008). Research by Browne, Edwards and Moore (2009) and by Mitchell (2010) reported evidence that unexpected shocks such as oil price shocks can have transitory effects on tourism in a few Caribbean destinations. A report by the World Tourism Organization in 2006 noted, for instance, that one of the short-term risks created with the increase in oil prices is that the frequency of tourist

\footnotetext{
18 Among all sets of results, greater weight is given to those estimated from the equation that controls for endogeneity and influential observations and that allows for country-specific effects (i.e. results from table 7 under the RE method).
} 
TABLE 6

Regression results ${ }^{\mathbf{a}}$

(Dependent variable $S_{i j}{ }^{b}$; sample 1995-2006; annual frequency)

\begin{tabular}{|c|c|c|c|c|c|c|}
\hline & \multicolumn{3}{|c|}{ Model specification A } & \multicolumn{3}{|c|}{ Model specification B } \\
\hline & $\mathrm{OLS}^{\mathrm{c}}$ & $\mathrm{GLS}^{\mathrm{d}}$ & Random Effects & $\mathrm{OLS}^{\mathrm{c}}$ & $\mathrm{GLS}^{\mathrm{d}}$ & Random Effects \\
\hline$Y_{j}$ & $\begin{array}{l}-0.0006 \\
(0.121)\end{array}$ & $\begin{array}{l}-0.0003 \\
(0.399)\end{array}$ & $\begin{array}{l}-0.0006 \\
(0.226)\end{array}$ & .. & .. & .. \\
\hline$Y_{U S}$ &.. & .. &.. & $\begin{array}{l}0.3984 * * \\
(0.029)\end{array}$ & $\begin{array}{l}0.3030^{*} \\
(0.067)\end{array}$ & $\begin{array}{l}0.3984^{*} \\
(0.090)\end{array}$ \\
\hline$Y_{w}$ & .. & .. &.. & $\begin{array}{l}1.5944 * * \\
(0.020)\end{array}$ & $\begin{array}{l}1.1521^{*} \\
(0.065)\end{array}$ & $\begin{array}{l}1.5944^{*} \\
(0.070)\end{array}$ \\
\hline GPOIL $_{j}$ & $\begin{array}{l}-0.0016 \\
(0.168)\end{array}$ & $\begin{array}{l}-0.0018^{*} \\
(0.088)\end{array}$ & $\begin{array}{l}-0.0016 \\
(0.267)\end{array}$ & .. & .. & .. \\
\hline$T C_{U K, j}$ &.. &.. & .. & $\begin{array}{l}-0.0077 * * \\
(0.021)\end{array}$ & $\begin{array}{l}-0.0053^{*} \\
(0.079)\end{array}$ & $\begin{array}{l}-0.0077^{*} \\
(0.064)\end{array}$ \\
\hline$T C_{U S, j}$ & .. & .. & .. & $\begin{array}{l}0.109 * * \\
(0.015)\end{array}$ & $\begin{array}{l}0.0430 * \\
(0.051)\end{array}$ & $\begin{array}{l}0.1095^{*} \\
(0.055)\end{array}$ \\
\hline$T C_{C A N, j}$ & .. & .. & .. & $\begin{array}{l}-0.0606 * * \\
(0.013)\end{array}$ & $\begin{array}{l}-0.0430 * \\
(0.051)\end{array}$ & $\begin{array}{l}-0.0606^{*} \\
(0.053)\end{array}$ \\
\hline$R E R_{j}$ & $\begin{array}{l}0.0004 * * * \\
(0.000)\end{array}$ & $\begin{array}{l}0.0003 * * * \\
(0.000)\end{array}$ & $\begin{array}{l}0.0004 * * * \\
(0.000)\end{array}$ & .. & .. & .. \\
\hline$R E R_{U K, j}$ & .. & .. & .. & $\begin{array}{l}-0.0478^{*} \\
(0.094)\end{array}$ & $\begin{array}{l}-0.0601 * * \\
(0.022)\end{array}$ & $\begin{array}{l}-0.0478^{*} \\
(0.100)\end{array}$ \\
\hline$R E R_{U S, j}$ & .. & .. & .. & $\begin{array}{l}-0.0388 \\
(0.565)\end{array}$ & $\begin{array}{c}0.0483 \\
(0.413)\end{array}$ & $\begin{array}{l}-0.0388 \\
(0.563)\end{array}$ \\
\hline$R E R_{C A N, j}$ & .. & .. & .. & $\begin{array}{l}0.2241^{* * *} \\
(0.005)\end{array}$ & $\begin{array}{l}0.1573 * * \\
(0.021)\end{array}$ & $\begin{array}{l}0.2241^{* * * *} \\
(0.008)\end{array}$ \\
\hline$I N V_{j}$ & $\begin{array}{l}-0.0001 \\
(0.934)\end{array}$ & $\begin{array}{l}-0.0004 \\
(0.683)\end{array}$ & $\begin{array}{l}-0.0001 \\
(0.948)\end{array}$ & $\begin{array}{c}0.0010 \\
(0.283)\end{array}$ & $\begin{array}{l}0.0021 * * \\
(0.012)\end{array}$ & $\begin{array}{c}0.0010 \\
(0.440)\end{array}$ \\
\hline GCONS $_{j}$ & $\begin{array}{l}-0.0082 * * * \\
(0.003)\end{array}$ & $\begin{array}{l}-0.0093 * * * \\
(0.000)\end{array}$ & $\begin{array}{l}-0.0082 * * * \\
(0.005)\end{array}$ & $\begin{array}{l}-0.0098^{* * * *} \\
(0.002)\end{array}$ & $\begin{array}{l}-0.0063 * * \\
(0.023)\end{array}$ & $\begin{array}{l}-0.0098 * * \\
(0.013)\end{array}$ \\
\hline TRADEOPEN $_{j}$ & $\begin{array}{l}-0.0014 * * * \\
(0.000)\end{array}$ & $\begin{array}{l}-0.0013 * * * \\
(0.000)\end{array}$ & $\begin{array}{l}-0.0014 * * * \\
(0.000)\end{array}$ & $\begin{array}{l}-0.0011 * * * \\
(0.000)\end{array}$ & $\begin{array}{l}-0.0011 * * * \\
(0.000)\end{array}$ & $\begin{array}{l}-0.0011 * * * \\
(0.000)\end{array}$ \\
\hline POPDENS $_{j}$ & $\begin{array}{l}1.0279 * * * \\
(0.000)\end{array}$ & $\begin{array}{l}0.8007 * * * \\
(0.000)\end{array}$ & $\begin{array}{l}1.0279 * * * \\
(0.000)\end{array}$ & $\begin{array}{l}1.6368 * * * \\
(0.000)\end{array}$ & $\begin{array}{l}1.0816^{* * * *} \\
(0.000)\end{array}$ & $\begin{array}{l}1.6368 * * * \\
(0.000)\end{array}$ \\
\hline${ }_{C R E D I T P S}$ & $\begin{array}{l}0.0040 * * * \\
(0.000)\end{array}$ & $\begin{array}{l}0.0033^{* * * *} \\
(0.000)\end{array}$ & $\begin{array}{l}0.0040 * * * \\
(0.000)\end{array}$ & $\begin{array}{l}0.0019 * \\
(0.079)\end{array}$ & $\begin{array}{c}0.0012 \\
(0.215)\end{array}$ & $\begin{array}{c}0.0019 \\
(0.154)\end{array}$ \\
\hline EMPLINDEX $_{j}$ & $\begin{array}{l}-0.3748 * * * \\
(0.000)\end{array}$ & $\begin{array}{l}-0.2922 * * * \\
(0.000)\end{array}$ & $\begin{array}{l}-0.3748 * * * \\
(0.000)\end{array}$ & $\begin{array}{l}-0.5992 * * * \\
(0.000)\end{array}$ & $\begin{array}{l}-0.4076^{* * * *} \\
(0.000)\end{array}$ & $\begin{array}{l}-0.5992 * * * \\
(0.000)\end{array}$ \\
\hline $\operatorname{COLSPAIN}_{j}$ & $\begin{array}{l}10.2161 * * * \\
(0.000)\end{array}$ & $\begin{array}{l}7.8508^{* * * *} \\
(0.000)\end{array}$ & $\begin{array}{l}20.0426 * * * \\
(0.000)\end{array}$ & $\begin{array}{l}17.0588 * * * \\
(0.000)\end{array}$ & $\begin{array}{l}11.7165^{* * *} \\
(0.000)\end{array}$ & .. \\
\hline $\mathrm{COLUK}_{j}$ & .. & .. & $\begin{array}{l}9.8265 * * * \\
(0.000)\end{array}$ & .. & .. & $\begin{array}{l}-17.0588 * * * \\
(0.000)\end{array}$ \\
\hline$E V I D_{j}$ & $\begin{array}{l}-2.7267 * * * \\
(0.000)\end{array}$ & $\begin{array}{l}-2.1065^{* * * *} \\
(0.000)\end{array}$ & $\begin{array}{l}-2.7267 * * * \\
(0.000)\end{array}$ & $\begin{array}{l}-4.3757 * * * \\
(0.000)\end{array}$ & $\begin{array}{l}-2.9453 * * * \\
(0.000)\end{array}$ & $\begin{array}{l}-4.3757 * * * \\
(0.000)\end{array}$ \\
\hline$A I D S_{j}$ & $\begin{array}{l}-0.0067 * * * \\
(0.000)\end{array}$ & $\begin{array}{l}-0.0049 * * * \\
(0.003)\end{array}$ & $\begin{array}{l}-0.0067 * * * \\
(0.001)\end{array}$ & $\begin{array}{l}-0.0121 * * * \\
(0.000)\end{array}$ & $\begin{array}{l}-0.0081 * * * \\
(0.000)\end{array}$ & $\begin{array}{l}-0.0121 * * * \\
(0.000)\end{array}$ \\
\hline$T U B E R_{j}$ & $\begin{array}{c}0.0011 \\
(0.217)\end{array}$ & $\begin{array}{c}0.0011 \\
(0.200)\end{array}$ & $\begin{array}{c}0.0011 \\
(0.339)\end{array}$ & $\begin{array}{l}-0.0012 \\
(0.278)\end{array}$ & $\begin{array}{l}-0.0020 * * \\
(0.044)\end{array}$ & $\begin{array}{l}-0.0012 \\
(0.376)\end{array}$ \\
\hline$T E L_{j}$ & $\begin{array}{l}0.0917 * * * \\
(0.000)\end{array}$ & $\begin{array}{l}0.0712 * * * \\
(0.000)\end{array}$ & $\begin{array}{l}0.0917 * * * \\
(0.000)\end{array}$ & $\begin{array}{l}0.1427 * * * \\
(0.000)\end{array}$ & $\begin{array}{l}0.0936^{* * * *} \\
(0.000)\end{array}$ & $\begin{array}{l}0.1427 * * * \\
(0.000)\end{array}$ \\
\hline Number of observations & 73 & 73 & 73 & 68 & 68 & 68 \\
\hline $\mathrm{R}$-square & 0.99 & .. & 0.99 & 0.99 & .. & 0.99 \\
\hline Wald statistic & $\begin{array}{c}8011.5 \\
(0.000)\end{array}$ & $\begin{array}{c}8004.1 \\
(0.000)\end{array}$ & $\begin{array}{l}8574.1 \\
\quad(0.000)\end{array}$ & $\begin{array}{c}4592.2 \\
(0.000)\end{array}$ & $\begin{array}{l}4554.1 \\
(0.000)\end{array}$ & $\begin{array}{l}4663.3 \\
\quad(0.000)\end{array}$ \\
\hline
\end{tabular}

Source: Author's estimations.

Note: The Hausman tests failed and thus are not reported.

a Including time dummies in all regressions. The dummies on years 2001-2005 were negative and significant at a $1 \%$ level in all three cases in model A. The dummy on year 2004 was negative and significant at a $5 \%$ level in two cases in model B. $P$-values in parentheses.

b For a definition of this variable and others used in the model, see section III.

c Ordinary least squares estimation with heteroskedasticity-corrected standard errors.

d Generalized least squares estimation allowing for cross-sectional heteroskedasticity only.

$*=$ significant at the $10 \%$ level, $* *=$ significant at the $5 \%$ level, $* * *=$ significant at the $1 \%$ level.

..$=$ not included, not applicable or dropped from the regression due to collinearity. 
TABLE 7

\section{Regression results ${ }^{\mathbf{a}}$}

(Dependent variable $S_{i j}$ b; sample 1996-2006; annual frequency)

\begin{tabular}{|c|c|c|c|c|c|c|}
\hline & \multicolumn{3}{|c|}{ Model specification A } & \multicolumn{3}{|c|}{ Model specification B } \\
\hline & $\mathrm{OLS}^{\mathrm{c}}$ & $\mathrm{GLS}^{\mathrm{d}}$ & Random Effects & $\mathrm{OLS}^{\mathrm{c}}$ & $\mathrm{GLS}^{\mathrm{d}}$ & Random Effects \\
\hline$Y_{j}$ & $\begin{array}{l}-0.0004 \\
(0.449)\end{array}$ & $\begin{array}{c}0.0004 \\
(0.272)\end{array}$ & $\begin{array}{l}-0.0004 \\
(0.558)\end{array}$ & .. & .. & .. \\
\hline$Y_{U S}$ & .. & .. & .. & $\begin{array}{c}0.2021 \\
(0.212)\end{array}$ & $\begin{array}{c}0.2122 \\
(0.168)\end{array}$ & $\begin{array}{c}0.2021 \\
(0.355)\end{array}$ \\
\hline$Y_{w}$ & .. & .. & .. & $\begin{array}{c}0.8413 \\
(0.177)\end{array}$ & $\begin{array}{c}0.8093 \\
(0.171)\end{array}$ & $\begin{array}{c}0.8413 \\
(0.322)\end{array}$ \\
\hline GPOIL $_{j}$ & $\begin{array}{l}-0.0013 * * * \\
(0.000)\end{array}$ & $\begin{array}{l}-0.0008 * * * \\
(0.088)\end{array}$ & $\begin{array}{l}-0.0013 * * * \\
(0.000)\end{array}$ &.. &.. &.. \\
\hline$T C_{U K, j}$ & .. & .. & .. & $\begin{array}{l}-0.0040 \\
(0.179)\end{array}$ & $\begin{array}{l}-0.0036 \\
(0.201)\end{array}$ & $\begin{array}{l}-0.0040 \\
(0.312)\end{array}$ \\
\hline$T C_{U S, j}$ & .. & .. & .. & $\begin{array}{c}0.0602 \\
(0.134)\end{array}$ & $\begin{array}{c}0.0508 \\
(0.163)\end{array}$ & $\begin{array}{c}0.0602 \\
(0.258)\end{array}$ \\
\hline$T C_{C A N, j}$ & .. & .. & .. & $\begin{array}{l}-0.0350 \\
(0.109)\end{array}$ & $\begin{array}{l}-0.0302 \\
(0.129)\end{array}$ & $\begin{array}{l}-0.0350 \\
(0.232)\end{array}$ \\
\hline Lagged $R E R_{j}$ & $\begin{array}{l}-0.0000 \\
(0.879)\end{array}$ & $\begin{array}{l}-0.0001 \\
(0.286)\end{array}$ & $\begin{array}{l}-0.0000 \\
(0.928)\end{array}$ & .. & .. & .. \\
\hline Lagged $R E R_{U K, j}$ & .. & .. &.. & $\begin{array}{l}-0.0198 \\
(0.537)\end{array}$ & $\begin{array}{l}-0.0487 * \\
(0.090)\end{array}$ & $\begin{array}{l}-0.0198 * \\
(0.539)\end{array}$ \\
\hline 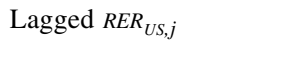 & .. & .. & .. & $\begin{array}{l}-0.0408 \\
(0.589)\end{array}$ & $\begin{array}{c}0.0551 \\
(0.360)\end{array}$ & $\begin{array}{l}-0.0408 \\
(0.570)\end{array}$ \\
\hline Lagged $R E R_{C A N, j}$ & .. & .. & .. & $\begin{array}{l}0.1378 * \\
(0.098)\end{array}$ & $\begin{array}{c}0.0804 \\
(0.250)\end{array}$ & $\begin{array}{l}0.1378 * \\
(0.097)\end{array}$ \\
\hline Lagged $I N V_{j}$ & $\begin{array}{l}0.0039 * * * \\
(0.000)\end{array}$ & $\begin{array}{l}0.0041 * * * \\
(0.000)\end{array}$ & $\begin{array}{l}0.0039 * * * \\
(0.012)\end{array}$ & $\begin{array}{l}0.0031 * * * \\
(0.001)\end{array}$ & $\begin{array}{l}0.0031^{* * *} \\
(0.000)\end{array}$ & $\begin{array}{l}0.0031^{* * *} \\
(0.034)\end{array}$ \\
\hline Lagged $G C O N S_{j}$ & $\begin{array}{l}-0.0110 * * * \\
(0.002)\end{array}$ & $\begin{array}{l}-0.0070 * * \\
(0.019)\end{array}$ & $\begin{array}{l}-0.0082 * * * \\
(0.005)\end{array}$ & $\begin{array}{l}-0.0104 * * * \\
(0.000)\end{array}$ & $\begin{array}{l}-0.0066 * * * \\
(0.007)\end{array}$ & $\begin{array}{l}-0.0104 * * * \\
(0.004)\end{array}$ \\
\hline Lagged TRADEOPEN & $\begin{array}{l}-0.0008^{* * * *} \\
(0.000)\end{array}$ & $\begin{array}{l}-0.0010^{* * * *} \\
(0.000)\end{array}$ & $\begin{array}{l}-0.0110 * * \\
(0.011)\end{array}$ & $\begin{array}{l}-0.0010 * * * \\
(0.000)\end{array}$ & $\begin{array}{l}-0.0011 * * * \\
(0.000)\end{array}$ & $\begin{array}{l}-0.0010^{* * *} \\
(0.000)\end{array}$ \\
\hline POPDENS $_{j}$ & $\begin{array}{l}1.3620 * * * \\
(0.000)\end{array}$ & $\begin{array}{l}0.9654 * * * \\
(0.000)\end{array}$ & $\begin{array}{l}1.3620 * * * \\
(0.000)\end{array}$ & $\begin{array}{l}1.5435^{* * * *} \\
(0.000)\end{array}$ & $\begin{array}{l}0.9343 * * * \\
(0.000)\end{array}$ & $\begin{array}{l}1.5435^{* * * *} \\
(0.000)\end{array}$ \\
\hline${\text { Lagged } C R E D I T P S_{j}}$ & $\begin{array}{l}0.0041 * * * \\
(0.000)\end{array}$ & $\begin{array}{l}0.0025 * * * \\
(0.004)\end{array}$ & $\begin{array}{l}0.0041 * * * \\
(0.003)\end{array}$ & $\begin{array}{l}0.0027 * * \\
(0.014)\end{array}$ & $\begin{array}{l}0.0025 * * * \\
(0.007)\end{array}$ & $\begin{array}{l}0.0027 * \\
(0.067)\end{array}$ \\
\hline EMPLINDEX $_{j}$ & $\begin{array}{l}-0.4975^{* * * *} \\
(0.000)\end{array}$ & $\begin{array}{l}-0.3565 * * * \\
(0.000)\end{array}$ & $\begin{array}{l}-0.4975^{* * * *} \\
(0.000)\end{array}$ & $\begin{array}{l}-0.5644 * * * \\
(0.000)\end{array}$ & $\begin{array}{l}-0.3476 * * * \\
(0.000)\end{array}$ & $\begin{array}{l}-0.5644 * * * \\
(0.000)\end{array}$ \\
\hline $\operatorname{COLSPAIN}_{j}$ & $\begin{array}{l}13.8995 * * * \\
(0.000)\end{array}$ & $\begin{array}{l}10.0422 * * * \\
(0.000)\end{array}$ & $\begin{array}{l}13.8995 * * * \\
(0.000)\end{array}$ & $\begin{array}{l}16.0136^{* * * *} \\
(0.000)\end{array}$ & $\begin{array}{l}9.8202 * * * \\
(0.000)\end{array}$ & $\begin{array}{l}28.0555^{* * * *} \\
(0.000)\end{array}$ \\
\hline $\mathrm{COLUK}_{j}$ & .. & .. & .. & .. & .. & $\begin{array}{l}-17.0588 * * * \\
(0.000)\end{array}$ \\
\hline$E V I D_{j}$ & $\begin{array}{l}-3.6248 * * * \\
(0.000)\end{array}$ & $\begin{array}{l}-2.5662 * * * \\
(0.000)\end{array}$ & $\begin{array}{l}-3.6248 * * * \\
(0.000)\end{array}$ & $\begin{array}{l}-4.1155^{* * * *} \\
(0.000)\end{array}$ & $\begin{array}{l}-2.5058 * * * \\
(0.000)\end{array}$ & $\begin{array}{l}-4.1155^{* * * *} \\
(0.000)\end{array}$ \\
\hline$A I D S_{j}$ & $\begin{array}{l}-0.0092 * * * \\
(0.000)\end{array}$ & $\begin{array}{l}-0.0062 * * * \\
(0.001)\end{array}$ & $\begin{array}{l}-0.0092 * * * \\
(0.001)\end{array}$ & $\begin{array}{l}-0.0111 * * * \\
(0.000)\end{array}$ & $\begin{array}{l}-0.0063 * * * \\
(0.001)\end{array}$ & $\begin{array}{l}-0.0111 * * * \\
(0.000)\end{array}$ \\
\hline$T U B E R_{j}$ & $\begin{array}{c}0.0001 \\
(0.894)\end{array}$ & $\begin{array}{l}-0.0006 \\
(0.474)\end{array}$ & $\begin{array}{c}0.0001 \\
(0.921)\end{array}$ & $\begin{array}{l}-0.0010 \\
(0.309)\end{array}$ & $\begin{array}{l}-0.0009 \\
(0.263)\end{array}$ & $\begin{array}{l}-0.0010 \\
(0.442)\end{array}$ \\
\hline$T E L_{j}$ & $\begin{array}{l}0.1173^{* * * *} \\
(0.000)\end{array}$ & $\begin{array}{l}0.0810 * * * \\
(0.000)\end{array}$ & $\begin{array}{l}0.1173 * * * \\
(0.000)\end{array}$ & $\begin{array}{l}0.1330 * * * \\
(0.000)\end{array}$ & $\begin{array}{l}0.0793 * * * \\
(0.000)\end{array}$ & $\begin{array}{l}0.1330 * * * \\
(0.000)\end{array}$ \\
\hline Number of observations & 66 & 66 & 66 & 68 & 68 & 68 \\
\hline $\mathrm{R}$-square & 0.99 & & 0.99 & 0.99 & & 0.99 \\
\hline Wald statistic & $\begin{array}{r}11671.7 \\
(0.000)\end{array}$ & $\begin{array}{r}11838.1 \\
(0.000)\end{array}$ & $\begin{array}{l}3140.4 \\
\quad(0.000)\end{array}$ & $\begin{array}{r}4869.7 \\
(0.000)\end{array}$ & $\begin{array}{r}4832.1 \\
(0.000)\end{array}$ & $\begin{array}{l}6540.0 \\
\quad(0.000)\end{array}$ \\
\hline
\end{tabular}

Source: Author's estimations.

Note: The Hausman tests failed and thus are not reported.

a Including time dummies in all regressions. The estimated coefficient for 2004 was negative and significant at the $10 \%$ level using either the OLS or the GLS estimation method in model A. The coefficient for 2005 was similarly negative and significant at a $10 \%$ level for the OLS and GLS estimations. In model B, the estimated coefficients for 2004 and 2005 were both negative and significant at the $10 \%$ level only using the ols method. $P$-values in parentheses.

b For a definition of this variable and others used in the model, see section III.

c Ordinary least squares estimation with heteroskedasticity-corrected standard errors.

d Generalized least squares estimation allowing for cross-sectional heteroskedasticity only.

$*=$ significant at the $10 \%$ level, $* *=$ significant at the $5 \%$ level, $* * *=$ significant at the $1 \%$ level.

..$=$ not included, not applicable or dropped from the regression due to collinearity. 
visits to some of the developing countries would decline as prices increased, making their tourism products less competitive with other destinations geographically closer to the major generating markets (UNWTO, 2006).

(ii) An increase in the share of gross fixed capital formation in GDP causes the share of world outbound American, British and Canadian tourists travelling to the Caribbean to increase in the following year, while a fall in the share of government final consumption expenditure in gdp increases the Caribbean's share of world outbound American, British and Canadian tourist arrivals in the following year. This evidence corroborates the policy recommendation made by the World Bank in its 2005 report on Caribbean competitiveness that policy regimes need to focus on public goods (such as infrastructure) rather than on incentives (World Bank, 2005). Investments that lead to improvements in the general infrastructure of a destination raise returns for the whole tourism sector as opposed to targeted public incentives, which raise returns for single private operators only. Focusing on general infrastructure rather than incentives provides a more holistic approach to raising destination competitiveness. Khadaroo and Seetanah (2008) found evidence as well that various forms of infrastructure, including transport infrastructure, are significant determinants of tourism demand for a given destination. However, a word of caution is in order here. This result is not taken to imply that governments do not have an important role in further stimulating competitiveness in the Caribbean, but rather it sheds light on the form that such government support should take. As noted in the World Bank report, the role played by governments in deepening the tourism benefits from emerging market niches is likely to become more complex. Governments have a key role to play in terms of setting the long-term strategic vision for the sector, stimulating linkages between tourism and the rest of the economy and building publicprivate partnerships in the sector.

(iii) A fall in the ratio of exports and imports to GDP causes the world share of outbound American, British and Canadian tourists travelling to the Caribbean to increase in the following year. The result is interpreted to imply that greater trade openness can harm tourism competitiveness. ${ }^{19}$ The

19 Greater trade openness can undermine local private sector development and the use of local products by foreign investors and high import leakage rates in Caribbean tourism (Meyer, 2006) signal an overuse of imported inputs to the detriment of locally sourced ones in the sector. In order to build competitiveness, the Caribbean needs to go beyond the traditional fare of mass tourism based on "sand, sun and sea" driven by foreign direct investment and heavy use of imported inputs and instead develop other stay-over segments, such as "culture and heritage tourism" and "community tourism", based on small, local enterprise development and the use of local goods and services. ${ }^{20}$

(iv) Increased domestic credit to the private sector and higher population density favour increases in the share of world outbound American, British and Canadian tourists travelling to the Caribbean. This supports the argument that development of the local private sector enhances the attractiveness of a given destination. Tourism competitiveness upgrading strategies based on selling the "local authenticity" of the destination to tourists seeking a cultural experience, for instance, rely on the supply of a whole range of locally produced goods and services. The supply of cheaper local products by the domestic private sector can also lower the costs of doing business in a given destination by allowing tourism investors to substitute away from the use of more-expensive imported inputs facilitated by open trade policies. The World Tourism Organization has been promoting the use of public-private partnerships as a way to enhance tourism competitiveness (WTO, 2000). A vibrant domestic private sector can be engaged to supply the finance and expertise needed to deepen the domestic tourism value chain. At the same time, higher population density - to the extent that it is associated with the supply of amenities and attractions - increases the attractiveness of a destination.

(v) An increase in the index of exposure to natural disasters, in reported new cases of HIV/AIDS and in labour market rigidities can cause, respectively, the share of world outbound British, American and Canadian tourists to fall. The negative impact of tropical storms and hurricanes on tourism arrivals in the Caribbean is obvious and has been well

can inhibit the development of the domestic tourism value chain, meaning the forging of linkages between the tourism sector and the rest of the local economy

20 See policy recommendation in World Bank (2005) and Bolaky (2008). 
documented. Granvorka and Strobl (2010) found econometric evidence of a significant negative impact of hurricanes on tourism arrivals. The relevance of a competitive and flexible labour market (leading to competitive wage levels) for Caribbean tourism was highlighted earlier by Randall and Wendel (2003). Their paper noted in reference to the Eastern Caribbean Currency Union countries that, given the prevailing fixed exchange rate regimes, the Union should seek to enhance wage competitiveness.

(vi) An increase in the number of telephone mainlines in use can increase tourism competitiveness. This result captures the relevance of technology in enhancing the attractiveness of a destination through, among others, its impact on utility costs. The International Monetary Fund (IMF, 2004) noted a sensitivity of tourism demand in the Caribbean to telecommunications costs. The report stated that, in CARICOM, there was a statistically significant negative relationship between hotel accommodation and both electricity and non-residential telephone subscription costs, indicating a negative association between operating costs and tourist arrivals.

(vii) The competitive advantage of the Spanish-speaking Caribbean relative to the English-speaking Caribbean is confirmed. This advantage persists even when differences in physical scale are controlled for.

\section{V \\ Conclusions: Main Drivers of Tourism Competitiveness in the Caribbean and Policy Recommendations}

This article has focused on only one ex post competitiveness indicator (namely, share in world arrivals), whereas it will be important to assess as well the factors that affect other measures of competitiveness, such as the share of tourism expenditure in GDP. Given the significance of the tourism sector in the Caribbean, there is an urgent need to undertake detailed country case studies in order to carefully analyse the determinants of tourism competitiveness by source market in most Caribbean countries.

Based on the above econometric results, the main findings are:

(i) A real exchange rate depreciation could increase tourism competitiveness, but only in relation to stay-over arrivals of Canadian tourists. In contrast, British tourists tend to be price-insensitive with regard to exchange rate fluctuations;

(ii) When increases in transport costs are linked to hikes in oil prices, there is a drop in stay-over arrivals, especially from Canada and the United Kingdom. It may be the case that this fosters tourism from the United States, as the Caribbean is a closer destination, with presumably lower air fares;

(iii) Former Spanish colonies seem to have an advantage in terms of tourism competitiveness over former British colonies; (iv) Other factors that negatively and robustly affect tourism competitiveness in the Caribbean include government consumption, trade openness, rigidities in the labour market and non-price factors such as environmental safety (measured by exposure to natural disasters and by the HIV/AIDS prevalence rate);

(v) Other factors that positively and robustly affect tourism competitiveness in the Caribbean include population density, domestic credit to the private sector, gross fixed capital formation in GDP and number of telephone mainlines in use;

(vi) There is no strong evidence that real income growth in source markets (i.e. Canada, the United Kingdom and the United States) plays a major role in tourism competitiveness behaviour in the Caribbean.

There is evidence that Caribbean competitiveness in stay-over tourism is slowing down; and this has been confirmed in previous studies by the International Monetary Fund, the World Bank and CARICOM. The region as a whole has not made any significant gains in the total world market share of stay-over arrivals for almost four decades. Thus, the Caribbean countries will need to find new ways to stimulate tourism competitiveness for greater economic gains. To maintain or enhance their tourism competitiveness, Caribbean destinations will need to become more cost- and price-competitive at 
home. This may involve supporting local private sector development in order to reduce import leakage and build linkages between the tourism sector and the rest of the economy, reducing government consumption to maintain competitive tax rates, reducing vulnerability to natural disasters, reforming labour markets and business regulations in general, maintaining a healthy and safe environment, investing in human development and technology and developing a transport/aviation policy that will result in lower transport costs to and from the region and greater air access.

The Caribbean will also need to reduce its vulnerability to external factors that are not within its control, such as income shocks from abroad and oil price shocks. Small, English-speaking Caribbean countries are particularly vulnerable, even more so in the context of the dominance of the larger, Spanish-speaking countries in the tourism sector, despite the embargo on Cuba. In the medium term, reducing vulnerability to external forces that can have a serious impact on tourism competitiveness will require further market diversification within the tourism sector as well as continually attracting priceand income-insensitive tourists from the upper end of the tourism markets. To this end, the creation and worldwide promotion of the "Caribbean brand" as a tourist destination would be very helpful and would also foster regional integration, a goal that has been pursued by Caribbean countries for decades.

(Original: English)

\section{Bibliography}

Archibald, Xiomara, Jason Lacorbinière and Winston Moore (2008), Analysis of Tourism Competitiveness in the Caribbean: A Gravity Model Approach, Bridgetown, Central Bank of Barbados/University of West Indies Cavehill Campus.

Bolaky, Bineswaree (2008), "Tourism life cycle, tourism competitiveness and upgrading strategies in the Caribbean" (LC/ CAR/L.166), Port of Spain, ECLAC subregional headquarters for the Caribbean, December.

(2007), "Tourism in the Caribbean: competitiveness, upgrading, linkages and the role of public-private partnerships and public policy" (LC/CAR/L.151), Port of Spain, ECLAC subregional headquarters for the Caribbean, December.

Browne, Rudolph, Laisha Edwards and Winston Moore (2009), Tourism and Unexpected Shocks, Bridgetown, Department of Economics, University of the West Indies Cavehill Campus.

CARICOM (Caribbean Community) (2005), "The competitiveness of Caribbean countries", Caribbean Trade and Investment Report 2005: Corporate Integration and Cross-Border Development, Georgetown.

Cervino, Julio and José María Cubillo (2005), "Hotel and tourism development in Cuba: opportunities, management challenges and future trends", Cornell Hotel and Restaurant Administration Quarterly, vol. 46, No. 2, Michigan Gale Group, May.

Cook, R. Dennis (1977), "Detection of influential observations in linear regression", Technometrics, vol. 19, No. 1, Alexandria, American Statistical Association.

Craigwell, Roland (2007), "Tourism competitiveness in small island developing states”, UNU-WIDER Research Paper, No. 2007/19, Helsinki, United Nations University (UNU)- World Institute for Development Economics Research (WIDER), April.

Craigwell, Roland and Delisle Worrell (2008), "The competitiveness of selected Caribbean tourism markets", Social and Economic Studies, vol. 57, No. 1, Kingston, Sir Arthur Lewis Institute of Social and Economic Studies (SALISES).

De Albuquerque, Klaus and Jerome McElroy (1992), "Caribbean smallisland tourism styles and sustainable strategies", Environmental Management, vol. 16, No. 5, New York, Springer.
Duval, David Timothy (2005), Tourism in the Caribbean: Trends, Development, Prospects, London, Routledge.

Dwyer, Larry and Chulwon Kim (2003), "Destination competitiveness: determinants and indicators", Current Issues in Tourism, vol. 6, No. 5, London, Routledge.

Dwyer, Larry, Peter Forsyth and Prasada Rao (2000), “The price competitiveness of travel and tourism destinations: a comparison of 19 destinations", Tourism Management, vol. 21, No. 1, Amsterdam, Elsevier.

ECLAC (Economic Commission for Latin America and the Caribbean) (2008a), Structural Change and Productivity Growth, 20 Years Later: Old Problems, New Opportunities (LC/ G.2367(SES.32/3)), Santiago, Chile.

(2008b), "Tourism life cycle, tourism competitiveness and upgrading strategies in the Caribbean" (LC/CAR.L.166), chapter 2, Port of Spain, ECLAC subregional headquarters for the Caribbean.

(2003), "Caribbean tourism, trends, policies and impact" (LC/ CAR/G.765), Port of Spain, ECLAC subregional headquarters for the Caribbean, December.

Gooroochurn, Nishaal and Guntur Sugiyarto (2005), "Competitiveness indicators in the travel and tourism industry", Tourism Economics, vol. 5, No. 11, London, IP Publishing Ltd.

(2004), "Measuring competitiveness in the travel and tourism industry", Discussion Papers, No. 2004/7, Nottingham, Nottingham University Business School.

Granvorka, Charley and Eric Strobl (2010), The Impact of Hurricanes Strikes on the Tourism in the Caribbean, St. Augustine, Sir Arthur Lewis Institute of Social and Economic Studies (SALISES), March.

Griffith, Jennifer (2000), "The impact of VAT on tourism in Barbados", Central Bank of Barbados Working Papers, Barbados, Central Bank of Barbados.

IMF (International Monetary Fund) (2004), "Eastern Caribbean currency union: selected issues", IMF Country Report, No. 04/335, Washington, D.C., April. 
Jayawardena, Chandana (2002), "Mastering Caribbean tourism", International Journal of Contemporary Hospitality Management, vol. 4, No. 2, Brighton, Emerald Publishing.

Kennedy, Peter (2007), A Guide to Econometrics, Oxford, WileyBlackwell Publishing.

Khadaroo, Jameel and Boopen Seetanah (2008), "The role of transport infrastructure in international tourism development: a gravity model approach", Tourism Management, vol. 29, No. 5, Amsterdam, Elsevier, October.

Mangion, Marie-Louise, Ramesh Durbarry and M. Thea Sinclair (2004), "Tourism competitiveness: price and quality", Discussion Papers, No. 2004/12, Nottingham, Nottingham University Business School.

McBain, Helen (2007), "Caribbean tourism and agriculture, linking to enhance development and competitiveness" (LC/CAR/L.076), Studies and Perspectives, No. 1, Port of Spain, EClaC subregional headquarters for the Caribbean, March.

Meyer, Dorothea (2006), Caribbean Tourism, Local Sourcing and Enterprise Development: Review of the Literature, Sheffield, Centre for Tourism and Cultural Change, Sheffield Hallam University.

Mitchell, Travis (2010), "The resilience of Caribbean tourism to external shocks", St. Augustine, Sir Arthur Lewis Institute of Social and Economic Studies (SALISES), March.

Odle, Maurice (2008), From Sub-prime to Sublime Disaster, Implications for the Caribbean Region of the Current Financial Crisis in the USA, Georgetown, Caribbean Community (CARICOM).

Randall, Ruby and Samuel Wendel (2003), "Tourism in the Eastern Caribbean: meeting the competitive threat", Eastern
Caribbean Currency Union: Selected Issues, IMF Country Report, No. 03/88, Washington, D.C., International Monetary Fund, March.

Romeu, Rafael (2008), "Vacation over: implications for the Caribbean of opening U.S.-Cuba Tourism”, IMF Working Papers, WP/08/162, Washington, D.C., International Monetary Fund, July.

Rosensweig, Jeffrey (1988), "Elasticities of substitution in Caribbean tourism", Journal of Development Economics, vol. 29, No. 1, Amsterdam, Elsevier, July.

Wilkinson, Paul F. (1997), Tourism Policy and Planning: Case Studies from the Commonwealth Caribbean, New York, Cognizant Communication Corporation.

World Bank (2005), A Time to Choose: Caribbean Development in the $21^{\text {st }}$ Century", Washington, D.C., April.

World Economic Forum (2007), The Travel \& Tourism Competitiveness Report 2007: Furthering the Process of Economic Development, Geneva.

World Travel and Tourism Council (2009), Travel and Tourism Economic Impact Caribbean 2009, London.

(2006), Tourism Satellite Accounting, London.

(2004), The Impact of Travel and Tourism on Jobs and the Economy, London.

wTo (World Tourism Organization) (2006), The Impact of Rising Oil Prices on International Tourism. Special Report number 26, Madrid.

(2000), Public-Private Sector Cooperation: Enhancing Tourism Competitiveness, Madrid. 